\title{
SHOULD CORPORATE GOVERNANCE AND CORPORATE SOCIAL RESPONSIBILITY WORK IN TANDEM?
} \author{
THE DEGREE OF \\ DOCTOR OF PHILOSOPHY \\ IN \\ BUSINESS ADMINISTRATION \\ MAY 2016 \\ By \\ Jaehyeon Kim \\ Dissertation Committee: \\ Shirley Daniel, Chairperson \\ Ghon Rhee \\ Jian Zhou \\ John Wendell \\ Seongah Im
}

A DISSERTATON SUBMITTED TO THE GRADUATE DIVISION OF THE UNIVERSITY OF HAWAI'I AT MĀNOA IN PARTIAL FULFILLMENT OF THE REQUIREMENTS FOR

Keywords: Corporate Governance, Corporate Social Responsibility, Firm Value, Credit Ratings 


\section{ACKNOWLEDGEMENTS}

I would like to express my deep sense of gratitude to Dr. Shirley Daniel for serving as Chair of my dissertation committee. I am indebted to her for her constant support. Her encouragement and guidance during the writing of this dissertation has enabled me to have successful completion. I could not have had a better advisor.

I also want to extend my gratitude to Dr. Ghon Rhee, Dr. Jian Zhou, Dr. John Wendell and Dr. Seongah Im for serving on my dissertation committee. Particularly, I want to thank Mrs. Mouzon Siddiqi for her help with editing. I also want to express my gratitude to Dr. KeeHong Bae at York University who has helped me solve difficult empirical problems. Lastly, I would like to express my deep sense of gratitude to my family for their great encouragement and unending support. 


\begin{abstract}
In addition to financial returns, investors and creditors are increasingly focused on corporate governance and corporate social responsibility (CSR) practices of their portfolio firms. Economic theories, such as agency theory and enlightened stakeholder theory explain the effects of corporate governance or CSR on corporate outcomes (Jensen and Meckling, 1976; Jensen, 2010). However, these economic theories do not adequately address the effects on corporate outcomes of interrelationships between corporate governance and CSR in a sophisticated manner. Koonce and Mercer (2005) note that psychology theories enable researchers to examine the behaviors of managers, auditors, investors and analysts in a concrete way. They further note that archival accounting researchers neglect psychology theories-despite their usefulness-for their research. Building on sensemaking theory from psychology (Starbuck and Milliken, 1988; Weick, 1995) and analyzing US firms from 1993 to 2006, I show that incongruent practices between corporate governance and corporate social responsibility causes investors and credit agencies to have equivocality about firms, leading to their negative identification of the firms which, in turn, decreases firm value and credit ratings. I show that having a balance between corporate governance and CSR is important for firm value and credit ratings. This dissertation makes contributions in terms of firm policy implications, in that management and board members of US firms often pay attention to shareholder value maximization, but disregard stakeholder concerns. This dissertation also helps correct misconceptions of some investors who focus too much on short-termism-believing that firms' engaging in CSR destroys firm value - by providing evidence that encouraging firms to pursue balanced corporate governance and CSR benefits investors and creditors, as well as society.
\end{abstract}




\section{TABLE OF CONTENTS}

ACKNOWLEDGEMENTS $\ldots \ldots \ldots \ldots \ldots \ldots \ldots \ldots \ldots \ldots \ldots \ldots$ ii

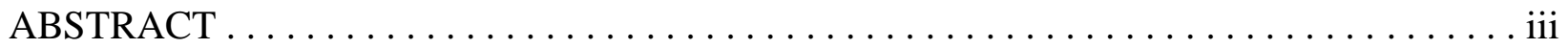

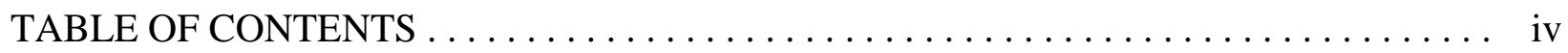

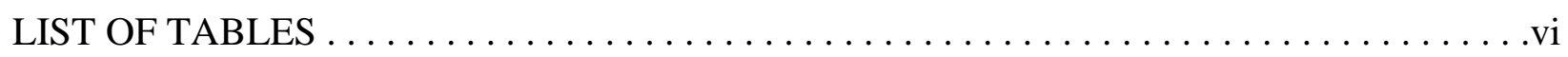

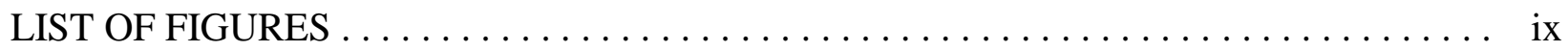

Chapter

I. INTRODUCTION $\ldots \ldots \ldots \ldots \ldots \ldots \ldots \ldots \ldots \ldots \ldots \ldots \ldots \ldots \ldots$

II. PRIOR LITERATURE $\ldots \ldots \ldots \ldots \ldots \ldots \ldots \ldots \ldots \ldots \ldots$

Relevant literature addressing the impact of corporate governance on firm

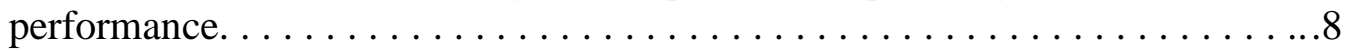
Relevant literature addressing the impact of CSR on corporate performance 8

III, THEORETICAL FRAMEWORK AND HYPOTHESIS $\ldots \ldots \ldots \ldots \ldots$

Enlightened value maximization or enlightened stakeholder theory $\rightarrow$

Enlightened balanced social corporate governance .............10

Sensemaking Theory and Hypothesis Development ...............11

IV. DATA, METHODOLOGY AND RESULTS $\ldots \ldots \ldots \ldots \ldots \ldots \ldots \ldots$

Sample construction and empirical model $\ldots \ldots \ldots \ldots \ldots \ldots \ldots \ldots \ldots \ldots \ldots$

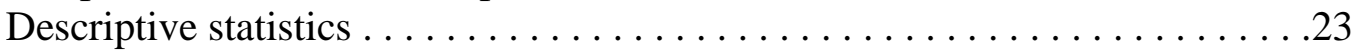

Empirical analyses................................ 25

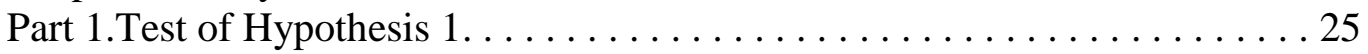

Part 1.1 Empirical results using Fama French 5 factor model. ...........25

Part 1.2. Portfolio analysis for Tobin's Q . . . . . . . . . . . . . . 29

Part 1.3 Difference analysis for Tobin's Q.....................30

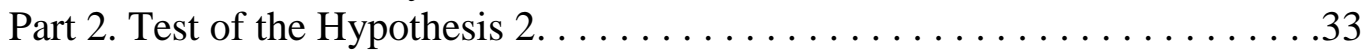

Part 2.1 Portfolio analysis for credit rating. . . . . . . . . . . . . . ...33

Part 2.2 Difference analysis for credit rating . . . . . . . . . . . . . 34

Part 3. Robustness check .............................. 35

V. CONCLUSIONS AND DISCUSSION $\ldots \ldots \ldots \ldots \ldots \ldots \ldots \ldots \ldots \ldots$

VI. LIMITATIONS AND FUTURE RESEARCH DIRECTIONS . . . . . . . . . . 44 
APPENDIX A. VARIABLE DEFINITION $\ldots \ldots \ldots \ldots \ldots \ldots \ldots \ldots \ldots \ldots \ldots \ldots \ldots \ldots \ldots$

APPENDIX B. EXPANDED LITERATURE REVIEW . . . . . . . . . . . . . . . . .66

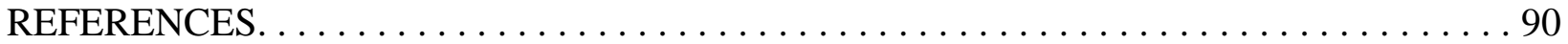




\section{LIST OF TABLES}

Table 1 Descriptive statistics for norcindex by year. $\ldots \ldots \ldots \ldots \ldots \ldots \ldots \ldots$

Table $2 \mathrm{a}$ Descriptive statistics for norgindex by year $\ldots \ldots \ldots \ldots \ldots \ldots \ldots \ldots \ldots \ldots \ldots \ldots \ldots \ldots$

Table $2 \mathrm{~b}$ Descriptive statistics for noreindex by year. $\ldots \ldots \ldots \ldots \ldots \ldots \ldots \ldots \ldots \ldots \ldots \ldots \ldots$

Table 3 Descriptive statistics for regression variables. . . . . . . . . . . . . . 46

Table 4 (a) Pearson Correlation. . . . . . . . . . . . . . . . . . . . . . . . .

Table 4(b) Spearman Correlation. . . . . . . . . . . . . . . . . . . . . 48

Table 5. Fama French 5 factor model with norgindex, norcindex. . . . . . . . . . . . . . . 49

Table 6. Fama French 5 factor model with noreindex, norcindex $\ldots \ldots \ldots \ldots \ldots \ldots \ldots$

Table 7. Abnormal return of a portfolio consisting of middle CG and middle CSR VS abnormal

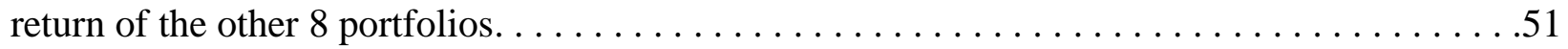

Table 8. Tobin's Q of a portfolio consisting of middle CG and middle CSR VS Tobin's Q of the other 8 portfolios, based on norgindex and norcindex or based on noreindex and norcindex . . .53

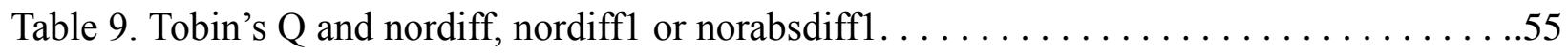

Table 10. credit rating of a portfolio consisting of middle CG and middle CSR VS credit rating of the other 8 portfolios, based on norgindex and norcindex or based on noreindex and

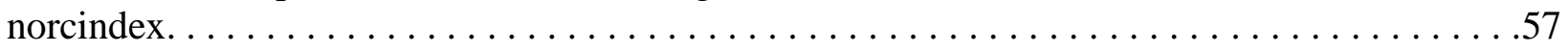

Table 11. Credit rating and nordiff, nordiff1 or norabsdiff $1 \ldots \ldots \ldots \ldots \ldots \ldots \ldots \ldots$

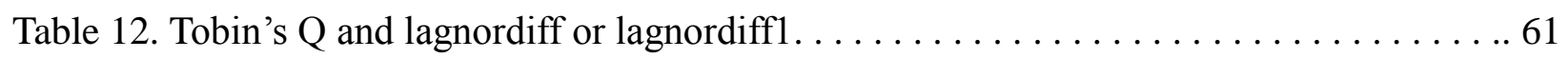

Table 13 Credit rating and lagnordiff or lagnordiff $1 \ldots \ldots \ldots \ldots \ldots \ldots \ldots \ldots \ldots \ldots \ldots \ldots \ldots \ldots$ 


\section{LIST OF FIGURES}

Figure 1. Incongruence between corporate governance and CSR . . . . . . . . . . . 12 


\section{CHAPTER I}

\section{INTRODUCTION}

According to a McKinsey Quarterly survey of more than one thousand board members and executives around the globe, conducted in early 2013, $79 \%$ of respondents felt pressure to show strong financial performance over a period of two years or less. Barton and Wiseman (2014) note that the emphasis of short-termism has been stronger, particularly in Western institutions, despite a proliferated sustainable capitalism framework. Baton (2011) notes "Myopia plagues Western institutions in every sector." In line with this, concentrating on short-termism, executives in US firms do not think that firms' engaging in corporate social performance is vital, though they agree that firms could not be profitable without society's support. However, people in society have been opining strongly that they have been playing a crucial role for firms' going concerns. These two differing views have engendered serious conflict in the US between society and business as to the nature of corporate responsibilities. According to Edelman Public Relations Agency's Trust Barometer issued in 2011, trust in companies in the US is around $45 \%$, whereas trust in companies is $61 \%$ in China, $70 \%$ in India and $81 \%$ in Brazil. In a book entitled Capitalism vs. Capitalism, published in 1991, Michael Albert (1993) distinguishes two models of capitalism: Rhine capitalism referred to as the stakeholder model, and neo-American capitalism called the shareholder model. In Rhine capitalism, he refers to countries along the river Rhine: Switzerland, Germany, the Netherlands with Sweden and, to a lesser extent, Japan. He notes that the stakeholder model strives for a long-term goal with cooperative efforts between management, labor and other stakeholders. He categorizes the US and UK as neo-American capitalism and posits that the shareholder model is filled with an "obsession with individual achievement and short-term profit." In the keynote 
address at the McKinsey Conference in 2012, Dezso Horvath, Dean of the Schulich School of Business, characterizes the shareholder model as having "much less sense of shared purpose and a tendency to leave the weaker members of society behind." He further notes that the shortterm objectives - the focus of the shareholder model-have triggered the recent economic meltdown referred to as the Great Recession. Donaldson and Preston (1995) note: "In America, for instance, shareholders have a comparatively big say in the running of the enterprises they own; workers ... have much less influence. In many European countries, shareholders have less say and workers more ... [I]n Japan . . managers have been left alone to run their companies as they see fit—namely for the benefit of employees and of allied companies, as much as for shareholders". The suggestion of Donaldson and Preston (1995) has been confirmed in the 2000s. Witt and Redding (2012) document in their survey that, in Japan, a high proportion of interviewed Japanese executives expressed their responsibilities to shareholders and employees. In contrast, a high percentage of the interviewed US executives answered that society can be an impediment to shareholder value creation; shareholder value maximization is a priority, while contributions to society are a secondary objective.

Instrumental stakeholder theory regards stakeholder management as a means for shareholder value creation. Applying this theory, firms can increase shareholder value through strategic spending on corporate social activities. The risk mitigation view of CSR indicates that corporate philanthropy decreases firm risks (McGuire et al., 1988; Starks, 2009). The literature suggests that firms' involvement in CSR develops good relationships with the community and the government, which, in turn, reduces the risk of litigation and government sanctions (McGuire et al, 1988; Peloza, 2006; Sharfman and Fernando, 2008; Dhaliwal, Eheitzman, and Li, 2009). Hence, CSR functions as insurance-like protection in preparation for significant and negative 
events (Godfrey, 2005; Gardberg and Fombrun, 2006; Godfrey et al., 2009). That is, the CSR value-enhancing view suggests that firms can increase their firm value, placing importance on social value such as environment, social equality and community relationships. Previous studies report the positive aspects of CSR such as the relationship of CSR reporting with a lower cost of capital (Dhaliwal et al., 2011), the association of stronger CSR with a lower cost of capital (Ghoul et al., 2011), the relationship of greater CSR with higher firm value (Galema et al., 2008), the relationship of higher CSR acquirers with higher merger announcement returns (Deng et al., 2013), and the association of higher CSR with more positive sell-side analysts' recommendations (Eccles et al., 2011).

However, some previous studies regard CSR as stemming from a managerial agency problem, referring to it as agency cost theory of CSR. Barnea and Rubin (2010) find that lower insiders' ownership is associated with higher CSR rating, showing that CSR is over-invested for the insiders' reputation when CSR-related costs do not put a great financial burden on them. Reinhardt et al. (2008) note that firms which are involved in unsustainable CSR may be out of business. They point out that the short-term results of unsustainable CSR are "loss of market share, increased insurance costs, increased borrowing costs, and loss of reputation"; the longterm results are "shareholder litigation, corporate takeover, or closure." Goss and Roberts (2011) find the association of higher discretionary CSR spending in low-quality borrowers with higher bank loan spreads and shorter maturities (Goss and Roberts, 2011). Surroca and Tribo (2008) document the relationship of stronger CSR with lower financial performance. That is, studies documenting the agency view of CSR suggest that managers pursue CSR, exploiting shareholders for their personal benefits.

Though the instrumental stakeholder theory and agency cost theory of CSR seem to be 
different, they have in common the belief that firms' focus on polishing their social image through CSR without "meaningful commitment to actual CSR" is a waste of resources (Huang and Watson, 2015).

- While prior literature explores corporate governance and CSR, only a few studies examine how the relationship between corporate governance and CSR is associated with corporate outcomes. Baker and Powell (2005) suggest that achieving shareholder wealth maximization should be done in a legally and socially responsible way. The strategy management literature challenges or extends agency theory by suggesting that noneconomic aspects, such as behavioral process theories in social psychology, should be applied to corporate governance research (Hambrick et al., 2008).

The two competing views, namely instrumental stakeholder theory and agency cost theory of CSR, may create challenges for investors and creditors in evaluating the appropriate level of emphasis to place on corporate governance and CSR. The theory of cognitive dissonance suggests that when two or more cognitions conflict with each other, individuals undergo an uncomfortable state of dissonance. Sensemaking theory calls this uncomfortable state caused by conflicting cues sensebreaking. It posits that the cognitive conflicts generated by sensebreaking are annoying and this leads to negative decisions. Given the fact that investors place importance on both corporate governance and CSR, like the survey ${ }^{1}$ results of fund managers, it is important to examine the effects on firm value of sensebreaking that may be occurring due to inconsistent policies for corporate governance and CSR.

${ }^{1}$ Mercer Investment Consulting (2006) asked fund managers about the importance of corporate governance and CSR on mainstream institutional investment analysis. The surveyed fund managers answered that corporate governance (64\%), sustainability (39\%), employee relations (33\%), human rights $(26 \%)$, water $(25 \%)$, environment management $(18 \%)$ and climate change (7\%) were very important. 
Theories such as contract theory and the theory of the firm suggest that "the interests of shareholders and other stakeholders in high CSR firms are in greater alignment than those of shareholders and other stakeholders in low CSR firms." (Deng et al., 2013). However, this is not always the case. Firms can exhibit stakeholder-centric behavior with overly strict pollution control standards, wasting their resources, which decreases shareholders' wealth. Or, firms can show strict shareholder-centric behavior-not caring about the environment or polluting the environment—which leads to redirecting their profits from shareholders to stakeholders to soften their negative image.

Drawing on sensemaking theory, I suggest that firms should have a balanced focus on corporate governance and CSR, with no lopsided focus on either corporate governance or CSR, since a negative external image stemming from an imbalance between corporate governance and CSR plays a significant role in lowering firm value and credit ratings. Particularly, using a sample from 1993 to 2006, I find strong evidence that greater incongruence between corporate governance and CSR is associated with lower firm value and credit ratings.

Jensen (2010) suggests an enlightened stakeholder theory, which posits that to maximize their long-term value, firms should consider both shareholders and stakeholders, making tradeoffs between the demands of all corporate constituencies, given no constituency can have complete satisfaction. However, he does not provide a specific explanation about how firms treat shareholders and non-shareholder stakeholders properly. Economic theories explain the effects of corporate governance or CSR on corporate outcomes. However, they do not discuss the effects on corporate outcomes of the relationship between corporate governance and CSR in a sophisticated manner. Koonce and Mercer (2005) note that psychology theories enable researchers to examine the behaviors of managers, auditors, investors and analysts in a concrete 
way. They note that archival accounting researchers neglect psychology theories for their research despite their usefulness. Building on sensemaking theory from psychology (Starbuck and Milliken, 1988; Weick, 1995), I show that firms' striking a balance between shareholder and stakeholder matters plays an important role in increasing firm value and credit ratings. I make three significant contributions to the literature: (1) Most prior literature explores the effect of corporate governance and CSR on corporate outcomes such as firm value (Ferrell et al, 2016) and credit rating (Jiraporn et al., 2014). However, they do not examine the impact of misaligned practices between corporate governance and CSR on corporate outcomes. This dissertation investigates the effect on corporate outcomes of the incongruent policies between corporate governance and corporate social responsibility. (2) This dissertation resonates with Koonce and Mercer (2005) in their call for archival accounting studies which rely on psychology theories based on their findings that there is a dearth of psychology-based archival research in top-tier accounting journals; heretofore, only two percent of archival financial accounting papers draw on psychology theories. (3) Walls et al. (2012) note that there is no clear prescription for the optimal design of a socially accountable governance structure, because there is only a short history of the corporate governance-CSR dynamic for the academic community to examine. I show that having a balance between corporate governance and CSR is important for firm value and credit ratings. This dissertation also makes contributions in terms of firm policy implications, in that management and board members of US firms often pay attention to shareholder value maximization, but disregard stakeholder concerns. Through this dissertation, they may realize that their lack of attention to stakeholders may be detrimental to the shareholder value maximization they are keen to uphold. Though corporate social responsibility has gained momentum recently, many US firms equate corporate social responsibility to only corporate 
philanthropy. This dissertation helps correct this misconception. This dissertation also helps correct misconceptions of some investors who focus too much on short-termism-believing that firms' engaging in CSR destroys firm value-by providing evidence that encouraging firms to pursue balanced corporate governance and CSR benefits not only them but also others. Clark et al. (2015) notes "from an investor's perspective, there exists a debate about the benefits of integrating sustainability criteria into the investment process, and the degree to which it results in a positive or negative return." This dissertation presents evidence that ignoring sustainability criteria for the investment decision in relation to corporate governance may cause significant negative abnormal returns

The remainder of the paper is organized as follows: Chapter 2 provides the literature review and develops testable hypotheses; Chapter 3 provides the data and methodology and presents the empirical results; Chapter 4 offers robustness tests; Section 5 contains conclusions and discussion. 


\section{CHAPTER II}

\section{PRIOR LITERATURE}

\section{$\underline{\text { Relevant literature addressing the impact of corporate governance on firm performance }}$}

Gompers et al. (2003) examines the association between the corporate governance score and firm performance. Before that, studies explored the relationship between some components of corporate governance such as the number of independent directors and separation of CEO and chairman, and corporate outcomes such as a company's credit rating, its stock price and operating performance. Gompers et al. (2003) is the first academic study to create a governance index (G_Score) from 24 provisions, and to investigate the effects of corporate governance on firm performance. Subsequent to Gompers et al. (2003), a number of studies have examined the association between governance scores and corporate outcomes. Bebchuk et al. (2009) create the entrenchment index with six provisions among the 24 provisions that the G_Score is based on. They find that the entrenchment index explains Tobin's Q and abnormal stock returns better than the G_Score. Brown and Calyor (2006) create another governance index based on 51 firm specific corporate governance provisions and find that seven provisions of the 51 provisions drive the relationship between corporate governance and firm value.

In sum, corporate governance studies examine the effects on corporate outcomes of various corporate governance provisions or corporate governance indices incorporating the overall corporate governance provisions. These studies demonstrate that firms with better corporate governance enjoy better corporate outcomes ${ }^{2}$.

Relevant literature addressing the impact of CSR on firm performance

Since the introduction of the Kinder, Lydenberg, and Domini (KLD) data, numerous

${ }^{2}$ More studies exploring the effect of corporate governance on firm performance are discussed in Appendix B. 
CSR studies have been published, particularly regarding the US firms. Before the KLD data introduction, CSR studies were usually conducted for the firms in Asia or Europe. Before the KLD data introduction, studies investigated the effects of some CSR components such as a firm's environmental policy on corporate outcomes. However, the KLD data have allowed for creating CSR scores. The studies find that CSR scores are related to corporate outcomes. Some studies find the positive effects of CSR (Dhaliwal et al., 2011; Ghoul et al., 2011; Galema et al., 2008), supporting the instrumental stakeholder theory, while others report negative effects of CSR (Surroca and Tribo, 2008), upholding the agency theory of CSR. However, the empirical CSR literature generally provides evidence that firms with a higher level of corporate social performance have better corporate outcomes ${ }^{3}$.

While prior empirical corporate governance studies document that firms with better corporate governance have higher firm value, they do not provide strong evidence regarding the association between better corporate governance and higher credit ratings as much as the relationship between stronger corporate governance and higher firm value. This is because corporate governance has a lopsided focus on shareholders, not addressing creditors' concerns.

CSR studies (Jiraporn et al., 2014; Attig et al., 2013) report that firms with better corporate social performance have higher credit ratings. While they show that a firm engaging in CSR contributes to shareholder value creation, they do not provide compelling evidence regarding the association between better CSR and higher firm value as much as the relationship between better CSR and higher credit ratings. This is because CSR does not address shareholders' concerns, but is more likely to address creditors' concerns.

\footnotetext{
${ }^{3}$ More studies exploring the effect of CSR on firm performance are discussed in Appendix B.
} 


\section{CHAPTER III}

\section{THEORETICAL FRAMEWORK AND HYPOTHESES}

\section{Enlightened value maximization or enlightened stakeholder theory $\rightarrow$ Enlightened}

\section{balanced social corporate governance}

Enlightened stakeholder theory is suggested by Jensen (2010). This theory is based on the assumption that value maximization cannot be accomplished without the support of stakeholders as well as shareholders. In enlightened value maximization, Jensen (2010) notes that firms should make tradeoffs between the demands of all corporate constituencies, given no constituency can have full satisfaction; however, he does not provide a specific explanation about how firms treat shareholders and non-shareholder stakeholders properly. Melding corporate governance and CSR, this dissertation proposes new terminology, "balanced social corporate governance (BSCG)" where firms should strike a balance between shareholder and stakeholder matters. As shown in figure 1 below, I propose that while good corporate governance (CG) and good CSR may individually have a positive impact on corporate outcomes, the incongruence between corporate governance and CSR may negatively impact corporate outcomes as a result of cognitive dissonance/sensebreaking of investors and creditors. The impact of the gap between CG and CSR on corporate outcomes is the primary research question in this dissertation. 
Figure 1. Incongruence between corporate governance and CSR

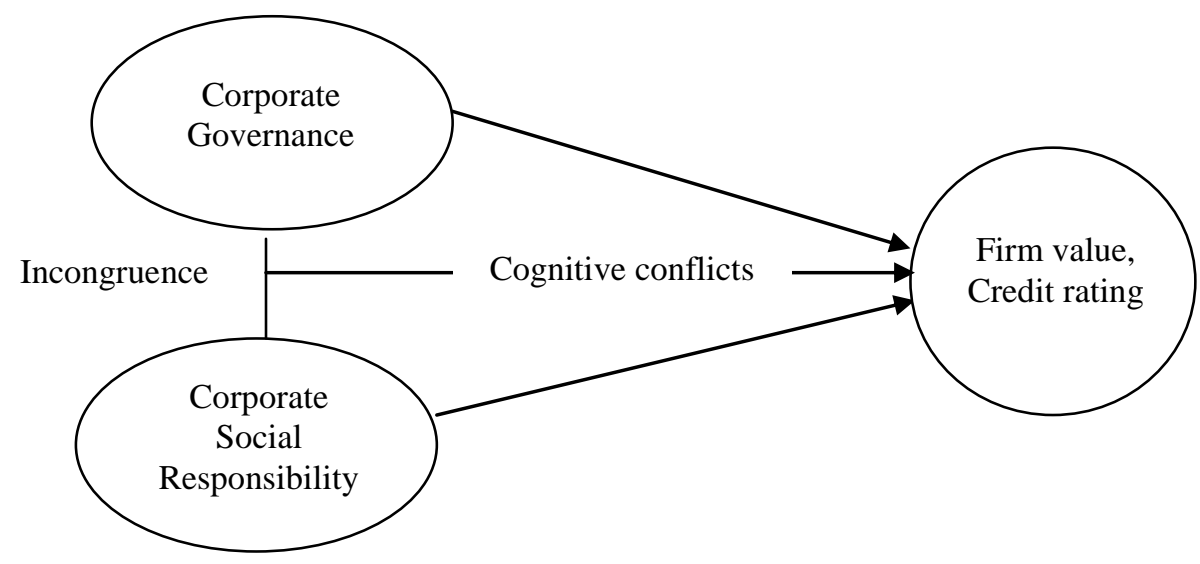

Good corporate governance lowers agency conflicts; good corporate social responsibility reduces societal conflict; and good congruence between CG and CSR decreases cognitive conflicts

\section{$\underline{\text { Sensemaking Theory and Hypothesis Development }}$}

$\underline{\text { Cognitive dissonance and firm value }}$

According to Coombes and Watson's (2000) survey, three quarters of investors surveyed in developed and emerging markets consider corporate governance as important as financial performance for their investment decision-making. Prior studies find that firms with strong corporate governance enjoy high firm value. Gompers et al. (2003) create a governance index, based on 24 provisions and document that the democracy portfolio, consisting of firms with the strongest shareholder rights (lowest governance index), earns much higher returns than the dictatorship portfolio consisting of firms with the weakest shareholder rights (highest governance index) (Gompers et al., 2003). Bebchuk et al. (2009) construct the E-index (the extent of entrenched managers), based on 6 provisions of Gompers et al.'s (2003) 24 provisions and find that increases in the E-index are related to lower Tobin's Q and lower stock returns. Based on Gompers et al.'s (2003) governance index, Cremers and Nair (2005) find that a portfolio that 
longs firms with the lowest governance index and shorts firms with the highest governance index enjoys positive abnormal returns of 10 to 15 percent when public pension fund (blockholder) ownership is high. On the contrary, they find no abnormal returns when public pension fund ownership is low.

Zingales (2000) and Jensen (2010) note that firms' investment in stakeholder welfare improves their reputation. Jiao (2010) and Jo and Harjoto (2011) document that firms with strong CSR exhibit high firm value. Galema et al. (2008) find that firms with better employee relations report excess returns. Edmans (2011) reports that the "100 Best Companies to Work For in America" enjoys superior shareholder return. Ghoul et al. (2011) show that a higher CSR score is related to a lower cost of equity. Atkas et al. (2011) provide evidence that in the merger and acquisition context, acquirers' gains are higher when they acquire the targets which better address social and environmental risks. Oikonomou et al. (2012) show that most of the individual corporate social concern factors are significantly positively associated with systematic firm risk.

Building on individual sensemaking, Dervin (1983, 1992, 1996) developed a theory regarding a human cognitive gap which occurs when people attempt to make sense of a situation. The sensemaking theory is applied in various areas including information science, human computer interaction, and psychology. In human computer interaction, Russel, Stefik, Pirolli and Card (1993) began to pay attention to sensemaking theory. In organization studies, Weick (1988) introduced sensemaking theory in the context of crisis situations.

The sensemaking theory tells us that individuals make decisions with observed data through the sensemaking process - attaching meaning to some target and placing this target into a mental framework (Starbuck and Milliken, 1988; Weick, 1995). Sensemaking undergoes the 
process of gathering information, gaining an understanding of the information and then using the understanding to finish a task. For instance, through sensemaking, individuals make decisions about whether to purchase an unfamiliar product or firms try to develop strategies to address globalization pressure (Sharma, 2006). According to Weick (1995), the sensemaking process is effective only with particular care. Without particular care, the sensemaking process is not effective, because individual beliefs rely on cues confirming their beliefs. Individuals tend to pay attention to observed data compatible with their beliefs, ignoring data which disconfirms their beliefs. Weick et al. (2005) note that "sensemaking involves the ongoing retrospective development of plausible images that rationalize what people are doing". Through the sensemaking process, individuals extract cues and make plausible sense retrospectively from ongoing circumstances (Weick et al., 2005). Sensemaking materializes meanings informing and constraining identity and action (Mills, 2003). Pratt shows that through the sensemaking process, dream-building and positive programming practices enable organization members to regard themselves as a part of an organization, which leads to a greater level of reliability for their organization. Sensebreaking and sensegiving are components of sensemaking. Sensebreaking is a gap-making process, while sensegiving is a gap-reducing process (Ashforth, Harrison, and Corley, 2008). Klein et al. (2006) observe "Sensemaking is a motivated, continuous effort to understand connections (which can be among people, places, and events)...." Individuals usually depend on various cues to make judgments and decisions. Sensebreaking occurs when individuals confront conflicting cues. These cues may cause people to trade off conflicting information. The cognitive cost of processing conflicting information is high. Sensebreaking has a negative influence on sensemaking. Sensebreaking leads individuals to undergo cognitive dissonance (Jia et al., 2004). Cognitive dissonance is an unpleasant state of 
tension (Koonce and Mercer, 2005). Faced with conflicting cues, people should resolve the cognitive dissonance to make their decisions. This is a nuisance. The conflicting information causes sensebreaking, which causes individuals to discredit entities. For instance, people go to a restaurant which is famous for food quality, expecting the service of the restaurant to be good; however, the service is bad in contrast to good food quality. This case illustrates sensebreaking. According to Pratt (2000), sensebreaking is "a meaning void that must be filled". Park and Rhee (2013) show that dispersion among the dimensions of MBA programs causes sensebreaking which, in turn, decreases the number of applicants to MBA programs. In terms of corporate governance and CSR, if corporate governance of a firm is good, whereas its CSR is poor (or vice versa), we can say that the firm has an incongruent reputation causing sensebraking. An incongruent reputation arising from a large difference between corporate governance and CSR causes individuals to have equivocality about the firm. Individuals regard this equivocality as surprise (Louis, 1980), disconfirmation (Weick and Sutcliffe, 2001), and breakdown (Patriotta, 2003). This equivocality causes individuals to view the firms as less reliable. Sensemaking theory suggests that reputation incongruence causes stakeholders to feel cognitive dissonance, which gives them a bad impression about firms with incongruent reputations (Pratt, 2000). Taken together, I argue that investors show preference of aversion to cognitive conflicts originating from inconsistent policies between corporate governance and CSR in addition to standard risk aversion. Thus, I hypothesize that an incongruent practice arising from a divergent record on corporate governance and CSR leads investors to be unwilling to make investments in firms with incongruent reputations which, in turn, decreases firm value. However, I do not say that firms with less incongruence between corporate governance and CSR always enjoy higher firm value. For instance, suppose that there are two firms: firm A with low 
corporate governance and low CSR and firm B with low corporate governance and high CSR (or high corporate governance and low CSR). In line with literature, I expect that the individual effects of corporate governance and CSR matters for firm value. Influenced by sensemaking theory, I also predict that congruence between corporate governance and CSR each impacts firm value. Thus, I do not necessarily argue that firm A with low corporate governance and low CSR has higher firm value than firm B with low corporate governance and high CSR (or high corporate governance and low CSR) or vice versa. Rather I hypothesize that, in addition to evaluating CG and CSR individually, the investors and credit raters will experience cognitive dissonance when they perceive inconsistencies in the firm's approaches to CG and CSR and will cope with this dissonance by assigning a lower credit rating or firm value.

H1: Greater incongruence between corporate governance and corporate social responsibility is associated with lower firm value.

Cognitive dissonance and credit rating

Credit agencies consider corporate governance in that firms with weak corporate governance are highly likely to experience impaired financial outcomes (FitchRatings, 2004). Standard \& Poor's corporate ratings consider CSR-related criteria for their ratings evaluation (Attig et al., 2013). Empirical studies present evidence that firms with stronger corporate governance enjoy higher credit ratings (Bhojraj and Sengupta, 2003; Liu and Jiaporn, 2010). In particular, Bhojraj and Sengupta (2003) suggest that good governance decreases agency and default risks and find that better corporate governance proxied by the higher percentage of shares owned by institutional investors and the higher percentage of independent directors on the board is associated with a higher level of bond ratings and a lower level of yields. Ashbaugh-Skaife et al. (2006) note that firms with lower Gompers et al.' (2003) G_Score (greater shareholder 
power) may enjoy higher credit ratings, since independent and proper monitoring of management can prevent managers from indulging in value-destroying activities, which in turn reduces firms' credit risk. However, they also note that bondholders and credit rating agencies may deem that a firm with a lower G_Score (stronger shareholder power) can decrease bondholders' wealth, since higher shareholder rights are more likely to change ownership which, in turn, leads to wealth transfer from bondholders to shareholders. They find that G_Score is marginally significantly positively related to credit ratings. That is, they marginally show that firms with greater shareholder rights suffer from lower credit ratings.

Attig et al. (2013) suggest that firms' corporate social activities increase long-term competitiveness and sustainability by cementing relationships with stakeholders and lessening the possibility of incurring costs resulting from socially irresponsible behavior which, in turn, decreases default risks. They find that firms with strong CSR enjoy high credit ratings. Jiraporn et al. (2014) also document that firms involved in a higher level of CSR have higher credit ratings. Sun and Cui (2013) provide evidence that CSR reduces firms' default risk.

In line with firm value, I posit that credit agencies take adverse identification of firms which have an imbalance between corporate governance and CSR. I argue that credit agencies regard as unstable firms with an incongruent policy between corporate governance and CSR; thus they view these firms as having a higher level of risk. Thus, I hypothesize that incongruence between corporate governance and CSR leads credit agencies to decrease credit ratings of the firms with the incongruence.

H2: Greater incongruence between corporate governance and corporate social responsibility is associated with lower credit ratings. 


\section{CHAPTER IV}

\section{DATA, METHODOLOGY AND RESULTS}

\section{$\underline{\text { Sample construction and empirical model }}$}

To test these hypotheses, I have drawn the measures for corporate governance from from Gompers et al. (2003) and the corporate social responsibility measures from Kinder, Lydenberg, Domini Research \& Analytics (KLD). Gompers et al. (2003) construct their governance index for the years 1990, 1993, 1995, 1998, 2000, 2002, 2004 and 2006. Kinder, Lydenberg, Domini Research \& Analytics (KLD) has produced their CSR index since 1991. Hence, the sample period of my main analyses covers the years 1993, 1995, 1998, 2000, 2002, 2004 and $2006 . \quad$ All other data for control variables (independent variables) and firm performance (dependent variables) are from Compustat and CRSP. To test the Hypothesis 1, I use a portfolio approach and measure performance by calculating abnormal returns for each portfolio and compare the returns for various combinations of CG and CSR ratings. In addition, I test Hypothesis 1 using the standard linear regression model (OLS) and measuring firm performance by Tobin's Q.

I estimate the abnormal returns of the equal-weighted portfolios by using the following Fama French 5 Factor Model:

$R_{i t}-R_{F t}=a_{i}+b_{i}\left(R M_{t}-R_{F t}\right)+s_{i} S M B_{t}+h_{i} H M L_{t}+r_{i} R M W_{t}+c_{i} C M A_{t}+e_{i t}$

$R_{i t}=$ return on security or portfolio $i$ for period $t$,

$R F_{t}=$ risk-free return

$R M_{t}=$ return on the value-weight $(V W)$ market portfolio

$S M B_{t}=$ return on a diversified portfolio of small stocks minus the return on a diversified portfolio of big stocks

$H M L_{t}=$ difference between the returns on diversified portfolios of high and low B/M stocks

$R M W_{t}=$ difference between the returns on diversified portfolios of stocks with robust and weak profitability

$C M A_{t}=$ difference between the returns on diversified portfolios of low and high investment stocks, which are called conservative and aggressive. 
Tobin's $Q=\alpha_{0}+\alpha_{1}$ norsdiff ${ }_{i, t}+\alpha_{2}$ gindex (or cindex) ${ }_{i, t}+\alpha_{3}$ controls $_{i, t}+\eta_{1} D_{\text {industry }}+\eta_{2} D_{\text {year }}+\varepsilon_{i, t}$ -> standard linear regression model (OLS)

Tobin's $Q=$ [book value of assets + (market value of equity - book value of equity)] / book value of assets

norsdiff $=$ norgindex - norcindex

To test Hypothesis 2, I use an ordered probit model to test for the impact of different levels and combinations of governance and CSR levels on firm credit ratings, based on prior studies (Blume et al., 1998; Bhojraj and Sengupta, 2003; Attig et al., 2013). The regression models used take the form of:

CREDIT RATING ${ }^{4}=f$ (nordiff, gindex (or cindex), controls, industry dummies, year dummies) -> ordered probit model

credit rating $=$ Standard $\&$ Poor's $(S \& P)$ domestic long-term issuer credit rating from $A A A$ (strongest capacity to pay interests on time and redeem principle when mature) to D (default on interest payments and principle). The letter ratings from $A A A$ to $D$ are converted into ranking numbers from 1 to 22. I multiply the ranking numbers by (-1). Thus -1 means the strongest capacity of payment, which is AAA.

Gompers et al. (2003) construct a governance index, using 24 governance provisions. They divide the 24 governance provisions into five categories: 1.tactics for delaying hostile takeover, 2. voting rights, 3 . director/officer protection, 4. other takeover defenses, 5. state laws. They create their governance index by summing 24 governance indicators. One point is added

${ }^{4}$ Hilscher and Wilson (2013) show that credit ratings do not predict default probability well. This dissertation focuses on the effect of the cognitive gap that credit agencies have from misaligned practices of corporate governance and corporate social responsibility. I do not examine default probability. 
to the index for each provision restricting shareholder rights. The possible range of the governance index is from 0 to 24 . A higher governance index means worse corporate governance. Therefore, I transform the governance index by [(the governance index $*(-1))+24]$ to get the ginde so that a higher gindex means better corporate governance. gindex $=($ governance index suggested by Gompers et al. $(2003)) *(-1)+24$

In addition, I create a normalized gindex, namely norgindex by dividing gindex by 24 to create a normalized score that ranges from 0 to 1 , representing the each firm's score in proportion to the best possible score on the Gompers index.

I measure a firm's CSR activity using the KLD database. KLD covered approximately 650 firms listed on the S\&P 500 Index or Domini 400 Social Index. Since 2003, KLD has expanded its coverage to the largest 3,000 US firms. KLD measures CSR of firms, using seven major dimensions: community, corporate governance, diversity, employee relations, environment, human rights, and product quality and safety. Each dimension contains positive (strength) and negative (concern) indicators. If a firm engages in a socially good activity, it gets one point on a strength indicator; if a firm engages in a socially bad activity, it gets one point on a concern indicator. I measure cindex by the sum of all KLD strength indicators minus the sum of all KLD concern indicators, following Jiao (2010) and Oikonomou (2012) ${ }^{5}$ as follows:

cindex $=($ sum of each community strength score - sum of each community concern score $)+$ (sum of each environment strength score - sum of each environment concern score) + (sum of each diversity strength score - sum of each diversity concern score) + (sum of each employee

${ }^{5}$ Following Hillman and Keim (2001) and Oikonomou (2012), I exclude the components related to alcohol, gambling, firearms, military, tobacco, and nuclear power, which KLD categorizes as controversial business, since firms in controversial business engage in CSR activities. Following Jiao (2010) and Oikonomou (2012), I also exclude the human rights dimension, since a strength (loss) indicator of the human rights dimension is related to a firm's social record in South Africa and Northern Island. 
relation strength score - sum of each employee relation concern score $)+($ sum of each product strength score - sum of each product concern score)

The maximum possible points of cindex are 28 points in 2000, 28 points in 2002,29 points in 2004 and 31 points in 2006. Therefore, I create a normalized cindex, namely nocinde ${ }^{6}$ by dividing cindex by 28,28, 29 and 31 in 2000, 2002, 2004 and 2006 respectively. The resulting variable represents the firm's CSR score for each year as a proportion of the highest possible score.

To measure the incongruence between the CG and CSR scores, I followed the technique of Park and Rhee (2013), whose study was designed to test whether higher dispersion among the dimensions of MBA programs, measured by standard deviation of the dimensions, causes greater reputation incongruence which, in turn, decreases the number of applicants to MBA programs. Following Park and Rhee (2013), I measure incongruent practices between corporate governance and CSR as the absolute value of the difference between the normalized measures of CG (norgindex) and CSR (norcindex) ${ }^{7}$.

nordiff $=$ difference between norgindex and norcindex

Based on the Gompers et al.' (2003) governance index, Bebchuk et al. (2009) create the

${ }^{6}$ Deng et al. (2013) suggest that the simple summation based on the KLD data has weakness, since the number of strength and concern indicators for dimensions varies from year to year. They note: "To overcome this issue, we construct another CSR measure by dividing the strength and concern scores for each dimension by the respective number of strength and concern indicators to derive adjusted strength and concern scores for that dimension and then taking the difference between the adjusted total strength score and the adjusted total concern score ("adjusted CSR score")". The approach of estimating norcindex is similar to their estimation approach.

7 Since I have two components, namely norgindex and norcindex, I should use the absolute value of the difference between norgindex and norcindex rather than the standard deviation of norgindex and norcindex. However, all firms in my sample higher norgindex than norcindex, I measure the incongruent practices as the difference between norgindex and norcindex, nor the absolute value of the difference between norgindex and norcindex. 
entrenchment index consisting of six provisions: staggered boards, limits to shareholder bylaw amendments, poison pills, golden parachutes, supermajority requirements for mergers, and charter amendments. They find that the entrenchment index explains Tobin's Q and abnormal stock returns better than the Gompers et al.'s (2003) governance index. Therefore, I also use an alternative measure of corporate governance based on Bebchuk's model. I transform the entrenchment index to eindex, so that the higher the eindex, the stronger the corporate governance

eindex $=[$ entrenchment index suggested by Bebchuk et al. $(2009)] *(-1)+6$

Then I create a normalized eindex, namely noreindex by dividing eindex by 6 , the highest possible score. I also measure incongruent practices between corporate governance and CSR as the absolute value of the difference between noreindex and norcindex.

nordiff $1=$ difference between noreindex and norcindex

norabsdiff $1=$ absolute value of the difference between noreindex and norcindex

Control variables in the model are as follows:

ni_ta $=$ net income scaled by total assets

lev $=$ total debt scaled by total assets

cash_ta = cash and cash equivalents scaled by total assets

capex_ta $=$ total capital expenditures scaled by total assets

lnasset $=$ nature log of total assets

int_cov = operating income before depreciation divided by interest and related expense.

cap_inten $=$ gross $P$ PE scaled by total assets

subordinate $=$ one if the firm has subordinate debt and zero otherwise 
$D_{\text {industry }}=$ array of industry dummy variables based on two-digit Standard Industrial Classification (SIC) codes

$D_{\text {year }}=$ array of year dummy variables

I include control variables from prior literature, (Claessens et al., 2002; Lins, 2003; Kalcheva and Lins, 2007; Lang et al., 2012). I control for ni_ta, since more profitable firms are more likely to have higher firm value. I include lev, since debts alleviate managerial agency problems (McConnell and Servaes (1990) and Harvey, Lins, and Roper (2004)). I also include cash_ta, since Lang et al. (2012) show that Tobin's Q tends to be higher for firms that have more cash. I control for capex_ta to proxy for potential investment opportunities. I also control for lnasset. Claessens et al. (2002) suggest that, on the one hand, firm size is expected to be positively related to firm value, since larger firms have better information environments, better disclosure and more liquid trading; on the other hand, firm size is expected to be negatively associated with firm value, because younger and smaller firms may have greater opportunity for growth. I also include interest coverage (int_cov) to control for firms' default risks and capital intensity (cap_inten) to proxy for firms' asset structure. Finally, I control for subordinate ${ }^{8}$, since subordinated debt is regarded as more risky. I include year and industry dummies to control for variations in firm value and credit rating over time and across industries, respectively. Petersen (2009) notes that under cross-sectional and time-series dependence, one can correct for cross-sectional dependence parametrically by including time indicators and correct for timeseries dependence by clustering by firms. Since I have many more firm observations than year observations, I employ year indicators and cluster standard errors by firm since a larger number of clusters produce less biased standard errors.

${ }^{8}$ binary variable equal to one if the firm has subordinated debt, zero otherwise. 


\section{$\underline{\text { Descriptive statistics }}$}

Table 1 reports descriptive statistics of norcindex over the sample period. The means of norcindex increases gradually from 1993 to 2000, but decrease gradually from 2000 to 2004 . Table 2a presents descriptive statistics for norgindex over the sample period. Its descriptive statistics from 1993 to 2006 are similar. Table 2 b reports descriptive statistics for noreindex over the sample period. Its descriptive statistics from 1993 to 2006 are similar to those of norgindex.

\section{Insert Tables $1,2 \mathrm{a}$ and $2 \mathrm{~b}$ here}

Table 3 provides descriptive statistics for variables used in the main tests. The median of the absolute value of the difference between norgindex and norcindex (norabsdiff) is 0.546 ; the median of the absolute value of the difference between noreindex and norcindex (norabsdiff1) is 0.565 . The sample firms have a median Tobin's $Q$ of 1.742 and a median credit rating of -9 , which corresponds to BBB. Median net income scaled by total assets (ni_ta) is 0.055 ; median total liabilities scaled by total assets (lev) are 0.536 . Median cash and cash equivalents scaled by total assets (cash_ta) is 0.053 ; median capital expenditures scaled by total assets (capex_ta) are 0.039 . The sample firms have a median log of total assets (lnasset) of 7.731.

\section{Insert Table 3 here}

Table 4a presents a pearson correlation matrix. Most correlations are significant at the $1 \%$ significance level. Tobin's $\mathrm{Q}$ is significantly positively correlated with credit rating. The correlation of norabsdiff with Tobin's Q is negative, whereas the correlation of norabsdiff1 with Tobin's Q is marginally significantly positive. The univariate analysis in the correlation table

point out the need to include relevant control variables in our models, as well as the need to consider and test for multicolinearity. Specifically, the univariate correlation between 
norabsdiff and norabsdiff1 and Tobin's Q is likely to be affected by other variables which are highly correlated with them and with Tobin's Q. Norgindex, noreindex and norcindex are significantly positively correlated with Tobin's Q. Tobin's Q is significantly correlated with all of control variables. This suggests that controlling for other firm characteristics is important to explore the association between Tobin's Q and incongruence between corporate governance and CSR. As far as the correlation between credit rating and key independent variables are concerned, I find that norabsdiff is significantly negatively correlated with credit rating. Norabsdiff1 is insignificantly positively correlated with credit rating. Again, because these results are based on the univariate analysis, not controlling for relevant control variables, the correlation between norabsdiff and credit rating may not be consistent with the correlation between norabsdiff1 and credit rating. Norcindex is significantly correlated with credit rating. Noreindex is significantly positively correlated with credit rating, whereas norgindex is significantly negatively correlated with credit rating. This may suggest that noreindex and norgindex represent different constructs, though noreindex is based on a subset of variables in norgindex. That is, this may show why it is important to measure incongruence between corporate governance and CSR with two corporate governance measures from Gompers et al.' (2003) governance index and Bebchuk et al' (2009) governance index in order to gain additional insights about factors influencing corporate governance as well as to test the robustness of the results.

\section{Insert Table 4a here}

Table $4 \mathrm{~b}$ presents a spearman correlation matrix. Most correlations are significant at the $1 \%$ significance level. Tobin's $\mathrm{Q}$ is significantly positively correlated with credit rating. The correlation of norabsdiff with Tobin's Q is negative. In contrast, the correlation of norabsdiff1 
with Tobin's Q is positive, but not significant. Norgindex, noreindex and norcindex are significantly positively correlated with Tobin's Q. Turning to the correlation between credit rating and key independent variables, I find that norabsdiff is significantly negatively correlated with credit rating, whereas norabsdiff1 is insignificantly negatively correlated with credit rating. Norcindex is significantly correlated with credit rating. I find that noreindex is significantly positively correlated with credit rating, whereas norgindex is significantly negatively correlated with credit rating.

Insert Table $4 \mathrm{~b}$ here

$\underline{\text { Empirical analyses }}$

\section{Part 1. Test of Hypothesis 1}

\section{Part 1. 1 Empirical results using Fama French 5 factor model}

Following Gompers et al. (2003) and Cremer and Nair (2005), I take a long-horizon approach to examine the empirical association between incongruence between corporate governance and CSR and firm performance based on abnormal return. I divide the firms into nine portfolios using three levels of corporate governance (CG) scores and three levels of CSR scores. The three levels of CG were determined as follows: low $\mathrm{CG}$ group $(0 \%<=\mathrm{CG}$ index $<$ $33.3 \%)$, middle $\mathrm{CG}$ group $(33.3 \%<=\mathrm{CG}$ index $<66.6 \%)$ and high $\mathrm{CG}$ group $(66.6 \%<=\mathrm{CG}$ index $<=100 \%$ ). I similarly divide the CSR group into three subgroups: low CSR group, middle CSR group and high CSR group. In another analysis, I divide CG group and CSR group into five subgroups based on quintile. Previous studies show that style of firms drive firm performance. Fama and French (2015) document that the Fama French 5 factor model performs better than the Fama French 3 factor model. That is, they show that in addition to market factor (beta), market capitalization (size), and book-to-market (value) that the Fama French 3 factor model is based on 
(Fama and French, 1993), firms' profitability and investment patterns affect stock returns. According to them, the Fama French 5 factor model accounts for $71 \%$ to $94 \%$ of the crosssectional variation of expected returns for the size, value, operating profit, and investment factors in the portfolios they investigate. Fama and French (2015) notes that the Fama French 3 factor model can be expanded with a momentum factor (Cahart, 1997) and a liquidity factor (Pastor and Stambaugh, 2003), but momentum and liquidity factors "have regression slopes close to zero and so produce trivial changes in model performance" (Fama and French, 2015).

I estimate the abnormal returns of the equal-weighted portfolios by using the following Fama French 5 Factor Model:

$R_{i t}-R_{F t}=a_{i}+b_{i}\left(R M_{t}-R_{F t}\right)+s_{i} S M B_{t}+h_{i} H M L_{t}+r_{i} R M W_{t}+c_{i} C M A_{t}+e_{i t}$

$R_{i t}=$ return on security or portfolio $i$ for period $t$,

$R F_{t}=$ risk-free return

$R M_{t}=$ return on the value-weight $(V W)$ market portfolio

$S_{M B}=$ return on a diversified portfolio of small stocks minus the return on a diversified portfolio of big stocks

$H M L_{t}=$ difference between the returns on diversified portfolios of high and low B/M stocks

$R M W_{t}=$ difference between the returns on diversified portfolios of stocks with robust and weak profitability

$C M A_{t}=$ difference between the returns on diversified portfolios of low and high investment stocks, which are called conservative and aggressive.

Table 5 is based on norgindex and norcindex. When CG is middle, the abnormal return gets bigger when CSR moves from low to middle and from middle to high; when CSR is middle, the abnormal return gets higher when CG moves from low to middle and from middle to high. When CG is low or high, the abnormal return increases when CSR moves from low to middle, but it decreases when CSR moves from middle to high. Also, when CSR is low or high, the abnormal return gets higher when CG moves from low to middle, but it gets lower when CG moves from middle to high. When CG is low, regardless of where CSR is located, or when 
CSR is low, regardless of where CG is located, the abnormal returns are significantly negative. The abnormal return of a portfolio consisting of a high CG group and a low CSR group and the abnormal return of a portfolio consisting of a low CG group and a high CSR group are significantly negative, whereas the abnormal return of a portfolio consisting of middle CG group and middle CSR group is negative, but not significant. Based on quintile, the abnormal return of a portfolio consisting of a middle CG group (40\%-60\%) and a middle CSR group (40\%-60\%) is insignificantly positive. The abnormal returns of portfolios consisting of a high CG group $(60 \%-80 \%$ or $80 \%-100 \%)$ and a low CSR group (0\%-20\% or $20 \%-40 \%)$ and the abnormal returns of portfolios consisting of a low CG group (0\%-20\% or 20\%-40\%) and a high CSR group (60\%-80\% or $80 \%-100 \%)$ are generally significantly negative. Unlike 3 X 3 portfolios, I do not find that the abnormal returns are significantly negative when CSR is in the lowest quintile. Like 3 X 3 portfolios, I find that the abnormal returns are significantly negative when CG is in lowest quintile.

\section{Insert Table 5 here}

Table 6 is based on noreindex and norcindex. Like the previous table, when CG is low, regardless of where CSR is located, or when CSR is low, regardless of where CG is located, the abnormal returns are significantly negative. Unlike the previous table, when CG is middle, the abnormal return gets higher when CSR moves from low to middle, but it gets lower when CSR moves from middle to high; when CSR is middle, the abnormal return increases when CG moves from low to middle, but it decreases when CG moves from middle to high. When CSR is low, the abnormal return increases when CG moves from low to middle and from middle to high. Also, when CG is low, the abnormal return becomes higher when CSR moves from low to middle, but it becomes lower when CSR moves from middle to high. The abnormal return of a 
portfolio consisting of a high CG group and a low CSR group and the abnormal return of a portfolio consisting of a low CG group and a high CSR group are significantly negative. I also find that the abnormal return of a portfolio consisting of a middle CG group and a middle CSR group is significantly negative, though its abnormal return is higher than the abnormal return of a portfolio consisting of a low CG group and a high CSR group and that of a portfolio consisting of a high CG group and a low CSR group. Based on quintile, the abnormal return of a portfolio consisting of a middle CG group (40\%-60\%) and a middle CSR group (40\%-60\%) is insignificantly positive. The abnormal returns of portfolios consisting of a high CG group (60\%-80\% or $80 \%-100 \%)$ and a low CSR group $(0 \%-20 \%$ or $20 \%-40 \%)$ and the abnormal returns of portfolios consisting of a low CG group (0\%-20\% or 20\%-40\%) and a high CSR group $(60 \%-80 \%$ or $80 \%-100 \%)$ are generally significantly negative. When CG is in the lowest quintile regardless of where CSR is located, I find no significantly negative abnormal returns. When CSR is in the lowest quintile, I find the significantly negative abnormal return when CG is located in $60 \%-80 \%$ and $80 \%-100 \%$.

\section{Insert Table 6 here}

Overall, in Tables 5 and 6 , I find that the abnormal return of a portfolio consisting of a high CG group and a low CSR group, and the abnormal return of a portfolio consisting of a low CG group and a high CSR group are significantly negative, whereas I do not find that the abnormal return of a portfolio consisting of a middle CG group and a middle CSR group is significantly negative. That is, I find that firms with incongruent policies for CG and CSR suffer from worse stock price performance.

In Table 7, I compare the abnormal return of a portfolio consisting of middle CG group and middle CSR group to the abnormal returns of the other 8 portfolios using regression with 
dummy variables to represent each of the 9 portfolios as defined using 3 levels each of norgindex and norcindex previously described. The baseline model is a portfolio consisting of middle CG group and middle CSR group. I find that the abnormal returns of 8 portfolios is not significantly different from the abnormal return of a portfolio consisting of middle CG group and middle CSR group except for the abnormal return of a portfolio consisting of high CG group and middle CSR group which is marginally significantly smaller than the abnormal return of a portfolio consisting of middle CG group and middle CSR group. Regression (2) creates the portfolios based on three levels each of noreindex and norcindex. I do not find that the abnormal returns of 8 portfolios are significantly different from the abnormal return of a portfolio consisting of middle CG group and middle CSR group.

\section{Insert Table 7 here}

To sum, though I do not find a very strong support, overall, I find that incongruent practices between corporate governance and CSR decreases abnormal returns.

\section{Part 1.2. Portfolio analysis for Tobin's Q}

I test whether Tobin's Q of 8 portfolios is significantly different from Tobin's Q of a portfolio consisting of middle corporate governance and middle CSR. In regression (1) of Table 19, I regress Tobin's Q on each portfolio based on norgindex and norcindex, and control variables. The baseline model is a portfolio consisting of middle CG firms and middle CSR firms. I find that Tobin's Q of a portfolio consisting of low CG firms and middle CSR firms is marginally significantly smaller than Tobin's Q of a portfolio consisting of middle CG firms and middle CSR firms. I find that Tobin's Q of a portfolio consisting of middle CG firms and high CSR firms is significantly larger than Tobin's Q of a portfolio consisting of middle CG firms and middle CSR firms. I do not find a statistically significant difference between Tobin's Q of a 
portfolio consisting of middle CG firms and middle CSR firms and Tobin's Q of a portfolio consisting of low CG firms and high CSR firms. I also do not find a statistically significant difference between Tobin's Q of a portfolio consisting of middle CG firms and middle CSR firms and Tobin's Q of a portfolio consisting of high CG firms and low CSR firms.

In regression (2), I regress Tobin's Q on each portfolio based on noreindex, norcindex and control variables. I find that Tobin's Q of a portfolio consisting of low CG firms and middle CSR firms is significantly smaller than Tobin's Q of a portfolio consisting of middle CG firms and middle CSR firms. I find that Tobin's Q of a portfolio consisting of middle CG firms and high CSR firms is significantly larger than Tobin's Q of a portfolio consisting of middle CG firms and middle CSR firms. I do not find the statistically significant difference between Tobin's Q of a portfolio consisting of middle CG firms and middle CSR firms and Tobin's Q of a portfolio consisting of low CG firms and high CSR firms. I also do not find the statistically significant difference between Tobin's Q of a portfolio consisting of middle CG firms and middle CSR firms and Tobin's Q of a portfolio consisting of high CG firms and low CSR firms.

Insert Table 8 here

To sum, I do not find that inconsistent practices between corporate governance and CSR decreases firm value.

\section{$\underline{\text { Part 1.3 Difference analysis for Tobin's Q }}$}

All firms in my sample have higher norgindex than norcindex. Thus I measure incongruence between corporate governance and CSR as the difference between norgindex and norcindex. That is, with norgindex, I can only test whether incongruence coming from strong corporate governance and weak CSR affects firm value and credit rating; however, I cannot test whether incongruence stemming from weak corporate governance and strong CSR influence 
firm value and credit rating in terms of sensemaking theory.

In regression (1) of Table 9, I regress Tobin's Q on norgindex, norcindex and control variables. The coefficient on norgindex is insignificantly positive, whereas the coefficient on norcindex is positive and highly significant. In regression (2), I regress Tobin's $\mathrm{Q}$ on nordiff (difference between norgindex and norcindex) ${ }^{9}$ and control variables. Nordiff has the negative coefficient at the 5\% significance level. Due to collinearity between norgindex, norcindex and nordiff, I do not regress Tobin's Q on norgindex, norcindex and norabsdiff, simultaneously. Instead, in regression (3), I regress Tobin's Q on norabsdiff, norgindex and control variables. The coefficient on norabsidff is negative at the $1 \%$ significance level. As far as the economic significance of norabsdiff is concerned in regression (2), one standard deviation increase in norabsdiff is associated with a 0.503 decrease in Tobin's Q. In regression (3), norgindex is positively associated with Tobin's Q at the $1 \%$ significance level, consistent with Gompers et al. (2003), but is not consistent with the one in regression (1). In regression (4), I regress Tobin's Q on nordiff, norcindex and control variables. The coefficient on norcindex is significantly positive, but the coefficient on nordiff is insignificantly positive. The result of regression (2) suggests that inconsistent practices between corporate governance and CSR play a significant role in decreasing firm value, though it is subject to the omitted variable bias. In regressions (1) to (4), Tobin's Q is higher for firms that have greater profitability, leverage, cash, capital expenditure and interest coverage, whereas Tobin's Q is lower for firms with larger size, greater capital intensity and more subordinate debts.

In regression (5), I regress Tobin's Q on noreindex, norcindex and control variables. The coefficients on noreindex and norcindex are positive and highly significant. Consistent with

\footnotetext{
${ }^{9}$ nordiff is always bigger than zero and thus nordiff is equal to norabdiff.
} 
Bebchuck et al. (2009), I find a greater effect on firm value of noreindex than norgindex. In regression (6), I regress Tobin's Q on nordiff1 (difference between noreindex and norcindex) and control variables. I do not find that nordiff1 is significantly negatively associated with Tobin's Q. In regression (7), I regress Tobin's Q on nordiff1, noreindex and control variables. I find that the coefficient on nordiff 1 is negative and highly significant, while noreindex has the significantly positive coefficient. In regression (8), I regress Tobin's Q on nordiff1, norcindex and control variables. The coefficient on nordiff1 turns significantly positive while the coefficient on norcindex is significantly positive. Fortunately, not all firms in my sample have higher noreindex than norcindex, though most firms have higher noreindex than nocinedex. Thus, I measure incongruence between corporate governance and CSR as the absolute value of the difference between noreindex and norcindex (=norabsdiff1) and regress Tobin's Q on norabsdiff1, noreindex, norcindex and control variables. The coefficient on norabsdiff1 to be negative at the $1 \%$ significance level. As far as the economic significance of norabsdiff1 is concerned in regression (4), one standard deviation increase in norabsdiff1 is associated with 1.770 decrease in Tobin's Q. Overall, the results of Table 9 document that sensebraking between corporate governance and CSR negatively affects firm value, while firms with stronger corporate governance or firms with stronger CSR enjoy higher firm value.

Insert Table 9 here

To sum, though there is an omitted variable problem and a muticollinearity problem, I find that imbalance between corporate governance and CSR lowers Tobin's Q. 


\section{Part 2. Test of Hypothesis 2}

Part 2.1 Portfolio analysis for credit rating

In regression (1) of Table 10, I regress credit rating on each portfolio based on norgindex, norcindex and control variables. The baseline model is a portfolio consisting of middle CG firms and middle CSR firms. I find that the credit rating of a portfolio consisting of middle CG firms and low CSR firms is significantly smaller than the credit rating of a portfolio consisting of middle CG firms and middle CSR firms. I find that the credit rating of a portfolio consisting of high CG firms and low CSR firms is marginally significantly smaller than the credit rating of a portfolio consisting of middle CG firms and middle CSR firms, which is inconsistent with the finding based on the univariate analysis. I find that the credit rating of a portfolio consisting of middle CG firms and high CSR firms is significantly larger than the credit rating of a portfolio consisting of middle CG firms and middle CSR firms.

In regression (2), I regress credit rating on each portfolio based on noreindex, norcindex and control variables. I find that the credit rating of a portfolio consisting of middle CG firms and lower CSR firms is marginally significantly smaller than the credit rating of a portfolio consisting of middle CG firms and middle CSR firms. I find that the credit rating of a portfolio consisting of middle CG firms and high CSR firms is marginally significantly larger than the credit rating of a portfolio consisting of middle CG firms and middle CSR firms. I do not find a statistically significant difference between the credit rating of a portfolio consisting of middle CG firms and middle CSR firms and the credit rating of a portfolio consisting of low CG firms and high CSR firms, which is inconsistent with the findings based on the univariate analysis. I also do not find the statistically significant difference between the credit rating of a portfolio consisting of middle CG firms and middle CSR firms and the credit rating of a portfolio 
consisting of high CG firms and low CSR firms.

Insert Table 10 here

To sum, I do not find that misaligned practices between corporate governance and CSR decreases credit ratings.

$\underline{\text { Part 2.2 Difference analysis for credit rating }}$

In regression (1) of Table 11, I regress credit rating on norgindex, norcindex and control variables. The coefficient on norgindex is significantly positive, whereas the coefficient on norcindex is positive and highly significant. In regression (2), I regress credit rating on nordiff (difference between norgindex and norcindex) and control variables. Nordiff has the negative coefficient at the $1 \%$ significance level. Due to collinearity between norgindex, norcindex and norabsdiff, I do not regress credit rating on norgindex, norcindex and norabsdiff, simultaneously. Instead, in regression (3), I regress credit rating on norabsdiff, norgindex and control variables. The coefficient on norabsidff is negative at the $1 \%$ significance level, while the coefficient on norgindex turns insignificantly positive. In regression (4), I regress credit rating on nordiff, norcindex and control variables. The statistical significance of coefficient on norcindex disappears while the coefficient on nordiff is significantly negative. The result of regression (2) suggests that inconsistent practices between corporate governance and CSR play a significant role in decreasing credit rating, though it is subject to omitted variable bias. In regressions (1) to (4), I find that credit rating tends to be higher for firms that have higher profitability, lower leverage, lower cash, greater assets, greater capital intensity and less subordinate debts.

In regression (5), I regress credit rating on noreindex, norcindex and control variables. The coefficient on noreindex is insignificantly positive, whereas the coefficient on norcindex is positive and highly significant. In regression (6), I regress credit rating on nordiff1 (difference 
between noreindex and norcindex) and control variables. I do not find that nordiff1 is significantly negatively associated with credit rating. In regression (7), I regress credit rating on nordiff1, noreindex and control variables. I find that the coefficient on nordiff1 is negative and highly significant, while the coefficient on noreindex turns significantly positive coefficient. In regression (8), I regress credit rating on nordiff1, norcindex and control variables. The coefficient on nordiff1 turns insignificantly positive while the coefficient on norcindex is significantly positive. In regressions (9), I regress credit rating on norabsdiff1, noreindex, norcindex and control variables. The coefficient on norabsdiff1 is negative, but not significant. Overall, the results of Table 11 weakly supports that sensebraking between corporate governance and CSR negatively affects credit ratings, while I do not have a strong finding that firms with stronger corporate governance or firms with stronger CSR enjoy higher credit ratings.

\section{Insert Table 11 here}

To sum, though there is an omitted variable problem and a muticollinearity problem, I find that incongruent practices between corporate governance and CSR lowers credit ratings.

\section{Part 3. Robustness check}

Using the difference analyses, I have attempted to test the Hypotheses 1 and 2. The findings based on the difference analyese have indicated that greater incongruence between corporate governance and CSR is related, with economic and statistical significance, to lower firm value and credit ratings. However, the findings do not ensure that greater incongruence plays an important role in decreasing firm value and credit ratings. Thus, I verify the stability of my evidence to potential endogeneity caused by reverse causality. Though the lagged value of a difference between norgindex (noreindex) and norcindex is associated with the current value 
of a difference between norgindex (noreindex) and norcindex, lagnorabsdiff ${ }^{10}$ and lagnorabsdiff1 ${ }^{11}$ cannot be the result of current Tobin's Q and credit rating.

In regression (1) of Table 12, I regress Tobin's $\mathrm{Q}$ on lagnorgindex, lagnorcindex and control variables. The coefficient on lagnorgindex is insignificantly positive, whereas the coefficient on lagnorcindex is positive and highly significant. In regression (2), I regress Tobin's Q on lagnordiff (difference between lagnorgindex and lagnorcindex) and control variables. Lagnordiff has the significantly negative coefficient. Due to collinearity between lagnorgindex, lagnorcindex and lagnorabsdiff, I do not regress Tobin's Q on lagnorgindex, lagnorcindex and lagnorabsdiff, simultaneously. Instead, in regression (3), I regress Tobin's Q on lagnorabsdiff, lagnorgindex and control variables. The coefficient on lagnorabsidff is negative at the $1 \%$ significance level. The coefficient on norgindex turns significantly positive. In regression (4), I regress Tobin's Q on lagnordiff, lagnorcindex and control variables. The coefficient on lagnorcindex is significantly positive, but the coefficient on lagnordiff is insignificantly positive..

In regression (5), I regress Tobin's $\mathrm{Q}$ on lagnoreindex, lagnorcindex and control variables. The coefficients on lagnoreindex and lagnorcindex are significantly positive. In regression (6), I regress Tobin's Q on lagnordiff1 (difference between lagnoreindex and lagnorcindex) and control variables. I do not find that lagnordiff1 is significantly negatively associated with Tobin's Q. In regression (7), I regress Tobin's Q on lagnordiff1, lagnoreindex and control variables. I find that the coefficient on lagnordiff1 is negative and highly significant, while lagnoreindex has the significantly positive coefficient. In regression (8), I regress Tobin's Q on nordiff1, norcindex and control variables. The coefficient on nordiff1

10 lagged value of a difference between norgindex and norcindex

11 lagged value of a difference between noreindex and norcindex 
turns significantly positive while the coefficient on norcindex is significantly positive. In lagged analysis, all firms in my sample have higher noreindex than norcindex, so I cannot regress Tobin's Q on norabsdiff1, noreindex, norcindex and control variables

\section{Insert Table 12 here}

In regression (1) of Table 13, I regress credit rating on lagnorgindex, lagnorcindex and control variables. The coefficient on lagnorgindex is negative, but not significant, whereas the coefficient on lagnorcindex is positive and highly significant. In regression (2), I regress credit rating on lagnordiff (difference between lagnorgindex and lagnorcindex) and control variables. The coefficient on lagnordiff has the negative coefficient at the $1 \%$ significance level. In regression (3), I regress credit rating on lagnorabsdiff, lagnorgindex and control variables. The coefficient on lagnorabsidff is negative at the $1 \%$ significance level. In regression (4), I regress credit rating on lagnordiff, lagnorcindex and control variables. The statistical significance of coefficient on norcindex disappears while the coefficient on lagnordiff is insignificantly positive. The result of regression (2) suggests that inconsistent practices between corporate governance and CSR lower credit rating, though it is subject to omitted variable bias.

In regression (5), I regress credit rating on lagnoreindex, lagnorcindex and control variables. The coefficient on lagnoreindex is insignificantly positive, whereas the coefficient on lagnorcindex is positive and highly significant. In regression (6), I regress credit rating on lagnordiff1 (difference between lagnoreindex and lagnorcindex) and control variables. The coefficient on lagnorabdiff1 is negative, but not significant. In regression (7), I regress credit rating on lagnordiff1, lagnoreindex and control variables. I find that the coefficient on lagnordiff1 is negative and highly significant, while the coefficient on lagnoreindex turns significantly positive. In regression (8), I regress credit rating on lagnordiff1, lagnorcindex and 
control variables. The coefficient on lagnordiff1 turns insignificantly positive while the coefficient on lagnorcindex is significantly positive.

\section{Insert Table 13 here}

The results of Tables 12 and 13 suggest that reverse causality does not unduly affect the main findings, at least to some extent. That is, though firms with great incongruence between corporate governance and CSR began the period with lower firm value and credit ratings, their firm value and credit ratings decreased further over time, which is consistent with the possibility that greater incongruence between corporate governance and CSR plays a significant role in lowering firm value and credit ratings. 


\section{CHAPTER VI}

\section{CONCLUSIONS AND DISCUSSION}

Managers tend to pay attention to social issues in an unproductive way, thereby sacrificing shareholder value (Jensen, 2010). Friedman (1970) expresses skepticism about firms' survival, if they are greatly concerned with society; he asserts that firms' focus on shareholders' objectives would be advantageous to both shareholders and stakeholders. Traditional finance theory posits that firms should care about shareholders only without considering stakeholders. However, focusing on shareholder matters only without caring for society can generate huge costs arising from environmental fines ${ }^{12}$, lawsuits and product liability suits. Through this dissertation, I have attempted to refute the traditional finance theory, trying to suggest that firms should pursue dual objectives of creating social value as well as financial value. To disprove the traditional finance theory in this dissertation, I have relied on three approaches: the Fama-French 5 factor model approach, portfolio analysis for Tobin's Q and an approach based on the difference between corporate governance and CSR. Using the FamaFrench 5 factor model, I generally find that firms with greater misalignment between corporate governance and CSR suffer from significantly negative abnormal returns. In the portfolio analysis for Tobin's Q and credit rating, I do not find that greater incongruence between corporate governance and CSR is related to lower Tobin's Q and lower credit rating. Using the approach based on the difference between corporate governance and CSR, I find that greater incongruence between corporate governance and CSR plays a significant role in decreasing Tobin's $Q$ and credit rating.

${ }^{12}$ Union Carbide Corporation in India paid \$470m (\$907m in 2014 dollars) to settle litigation stemming from a leak of chemicals in its factory in 1984, which led to the death of thousands. 
There are strengths and weakness of each three method. The abnormal return approach has a strength in that it is widely used in the finance literature; however, its weakness is that I cannot measure within-variation in each portfolio, though I can measure variation between two portfolios. Also, this portfolio approach might produce different results based on $3 \mathrm{X} 3,4 \mathrm{X} 4$, $5 \mathrm{X} 5, \ldots, 10 \mathrm{X} 10$ portfolios and so on.

The portfolio analysis for Tobin's Q and credit rating has a strength in that I can include the relevant control variables; however, its weakness is that the portfolio analysis for Tobin's Q and lower credit rating does not allow for considering the variation within a portfolio, namely within-variation; it only allows for measuring the variation between two portfolios, namely between-variation only.

Overall, though I do not have a strong support, I find that greater congruence between corporate governance and CSR is important for Tobin's Q, abnormal return, and credit ratings, suggesting that firms should practice shareholder and stakeholder management in a balanced way.

\section{Theoretical contribution}

Sociology and organizational behavior proposes the stakeholder theory (Jensen, 2010). It posits that firms should weigh up all corporate constituents who contribute to firms by human, social, or financial capital. Economic theories such as instrumental stakeholder theory and the agency cost theory of CSR attempt to shed light on whether firms' favorable treatment of stakeholders enhances shareholders' value or not. However, the stakeholder theory, instrumental stakeholder theory and agency cost theory of CSR do not tackle the impacts on corporate outcomes of the gap between corporate governance and CSR in a sophisticated manner. At best, Jensen's (2010) enlightened stakeholder theory suggests that firms should value corporate governance and CSR, making a tradeoff between them. However, it does not 
expound on how the firms should give weight to corporate governance and CSR. Koonce and Mercer (2005) note that using psychological theories may allow better insights on the behaviors of managers, auditors, investors and analysts in more depth. The strategy management literature underscores that noneconomic aspects, such as behavioral process theories in social psychology, should be applied to corporate governance research (Hambrick et al., 2008). Sensemaking theory (Starbuck and Milliken, 1988; Weick, 1995) based on psychology suggests that conflicting information leads individuals to make unfavorable decisions about entities causing cognitive dissonance. Drawing on sensemaking theory, I document that firms' congruent policies between corporate governance and CSR can enhance firm value and credit ratings. This dissertation's findings point to the need to bring psychology theories and behavioral impacts into the design of corporate governance/CSR theories.

\section{$\underline{\text { Literature contribution }}$}

This dissertation also contributes to academic research in three ways. (1) While most prior research (Ferrell et al., 2016, Jiraporn et al., 2014) examines the effect of corporate governance and CSR on corporate outcomes, no studies investigate the impact on corporate outcomes of the incongruent practices between corporate governance and CSR. This dissertation presents an in-depth discussion about how the imbalance between corporate governance and CSR impacts corporate outcomes. (2) This dissertation adds to psychologybased archival research, of which there has been very little to date. Koonce and Mercer (2005) note that only two percent of archival financial accounting papers in top-tier accounting journals draw on psychology theories. (3) Walls et al. (2012) suggest that there is no optimal solution for a socially accountable governance structure with a short history of the corporate governanceCSR dynamic for the academic community to examine. I show that having a balance between 
corporate governance and CSR is important for firm value and credit ratings.

\section{$\underline{\text { Practical contribution }}$}

The New York Times (Feb 7, 2016) reports that a firm which has not addressed stakeholders' problems properly has undergone stock pitfalls. A share price in Peabody Energy was around $\$ 1,000$ in 2011 ; however, its price dropped dramatically to around $\$ 4$. The New York Times reports that their improper disclosure about how climate risks affect its business has led it stock price to tumble. This shows the importance of tackling stakeholders' issues promptly is.

The New York Times (Feb 1, 2016) reports that Laurence D. Fink, co-founder and chief executive of BlackRock sent a letter to CEOs of 500 companies to ask companies to take into consideration environmental and social issues as well as governance issues, pointing out "These issues have long been an afterthought for most companies and in particular, for investors, who have simply sought companies that deliver the highest returns." and "These issues offer both risks and opportunities, but for too long, companies have not considered them core to their business - even when the world's political leaders are increasingly focused on them, as demonstrated by the Paris climate accord."

This dissertation contributes to practice demonstrating that US firms' one-sided focus on shareholder value maximization away from stakeholders' concerns undermines the principle of shareholder value maximization to which the firms are eager to adhere. Corporate management should not cause cognitive conflicts of corporate audiences such as investors and creditors, arising from a divergent record on corporate governance and CSR. Good corporate governance lowers agency conflicts; good social responsibility reduces societal conflicts. This dissertation documents that a good balance between corporate governance and CSR decreases cognitive 
conflicts of corporate audiences. 


\section{CHAPTER VII}

\section{LIMITATIONS AND FUTURE RESEARCH DIRECTIONS}

Gompers et al.'s (2003) governance index consisting 24 firm-specific provisions, and Bebchuk et al.'s (2009) entrenchment index made up of 6 provisions among the Gomper et al.'s (2003) governance index, are based on anti-takeover measures related to external governance (Cremer and Nair, 2005). Cremers and Nair (2005) suggest that both external and internal governance are associated with firm value. Future research needs to explore how the imbalance between CSR and corporate governance consisting of external and internal governance affects corporate outcomes such as firm value and credit rating. This dissertation is based on the corporate governance index and CSR index derived from summing provisions in a binary way. However, some provisions may be more important than others. Future research needs, more thoroughly, to put different weights on these provisions to examine the effects of incongruent practices between corporate governance and CSR on corporate outcomes. The results of this dissertation are based on archival research. They may be strengthened by experiment research which allows for randomization, mitigating endogeniety problems. This dissertation is based on US firms, which are influenced heavily by a shareholder-centric view. It will be interesting to examine whether this dissertation's results can be applied to firms which are affected materially by a stakeholder centric view. 
Table 1 Descriptive statistics for norcindex by year

\begin{tabular}{ccccccc}
\hline Year & Obs & Mean & Q1 & Median & Q3 & Std \\
\hline 1993 & 604 & 0.012 & -0.037 & 0.000 & 0.074 & 0.085 \\
1995 & 595 & 0.022 & -0.034 & 0.000 & 0.069 & 0.085 \\
1998 & 604 & 0.032 & -0.036 & 0.036 & 0.107 & 0.089 \\
2000 & 596 & 0.037 & 0.000 & 0.036 & 0.080 & 0.091 \\
2002 & 596 & 0.017 & -0.036 & 0.000 & 0.071 & 0.080 \\
2004 & 1192 & -0.003 & -0.034 & 0.000 & 0.0345 & 0.070 \\
2006 & 1155 & -0.002 & -0.032 & 0.000 & 0.032 & 0.078 \\
\hline
\end{tabular}

Table 2a Descriptive statistics for norgindex by year

\begin{tabular}{ccccccc}
\hline Year & Obs & Mean & Q1 & Median & Q3 & Std \\
\hline 1993 & 604 & 0.545 & 0.462 & 0.538 & 0.615 & 0.106 \\
1995 & 595 & 0.542 & 0.462 & 0.538 & 0.615 & 0.103 \\
1998 & 604 & 0.542 & 0.462 & 0.538 & 0.615 & 0.101 \\
2000 & 596 & 0.549 & 0.462 & 0.538 & 0.615 & 0.101 \\
2002 & 596 & 0.564 & 0.500 & 0.577 & 0.644 & 0.102 \\
2004 & 1192 & 0.576 & 0.500 & 0.577 & 0.654 & 0.099 \\
2006 & 1155 & 0.576 & 0.500 & 0.577 & 0.654 & 0.098 \\
\hline
\end{tabular}

Table 2b Descriptive statistics for noreindex by year

\begin{tabular}{ccccccc}
\hline Year & Obs & Mean & Q1 & Median & Q3 & Std \\
\hline 1993 & 555 & 0.596 & 0.500 & 0.667 & 0.667 & 0.221 \\
1995 & 545 & 0.598 & 0.500 & 0.667 & 0.667 & 0.218 \\
1998 & 552 & 0.588 & 0.500 & 0.500 & 0.667 & 0.219 \\
2000 & 532 & 0.596 & 0.500 & 0.667 & 0.833 & 0.219 \\
2002 & 523 & 0.589 & 0.500 & 0.500 & 0.667 & 0.211 \\
2004 & 1048 & 0.585 & 0.500 & 0.500 & 0.667 & 0.211 \\
2006 & 1037 & 0.590 & 0.500 & 0.500 & 0.667 & 0.206 \\
\hline
\end{tabular}


Table 3 Descriptive statistics for regression variables

\begin{tabular}{ccccccc}
\hline Variable & Obs & Mean & P25 & Median & P75 & Std \\
\hline Tobin's Q & 4154 & 2.342 & 1.320 & 1.742 & 2.485 & 2.456 \\
credit rating & 2391 & -8.597 & -11.000 & -9.000 & -6.000 & 3.369 \\
norabsdiff & 5072 & 0.550 & 0.462 & 0.546 & 0.648 & 0.131 \\
norabsdiff1 & 4553 & 0.580 & 0.412 & 0.565 & 0.731 & 0.225 \\
ni_ta & 4222 & 0.045 & 0.023 & 0.055 & 0.094 & 0.214 \\
lev & 4254 & 0.537 & 0.385 & 0.536 & 0.670 & 0.232 \\
cash_ta & 4191 & 0.088 & 0.019 & 0.053 & 0.122 & 0.099 \\
capex_ta & 4182 & 0.054 & 0.021 & 0.039 & 0.070 & 0.051 \\
lnasset & 4267 & 7.815 & 6.729 & 7.731 & 8.834 & 1.536 \\
\hline
\end{tabular}


Table 4(a) Pearson Correlation

\begin{tabular}{|c|c|c|c|c|c|c|c|c|c|c|c|}
\hline & Tobin's Q & $\begin{array}{l}\text { credit } \\
\text { rating }\end{array}$ & norabsdifff & norabsdiff 1 & norgindex & noreindex & norcindex & ni_ta & lev & cash_ta & capex_ta \\
\hline $\begin{array}{l}\text { credit } \\
\text { rating }\end{array}$ & $0.205^{* * *}$ & & & & & & & & & & \\
\hline norabsdiff & $-0.058 * * *$ & $-0.245 * * *$ & & & & & & & & & \\
\hline norabsdiff1 & $0.028^{*}$ & 0.007 & $0.734 * * *$ & & & & & & & & \\
\hline norgindex & 0.048 *** & $-0.088 * * *$ & $0.781 * * *$ & $0.685 * * *$ & & & & & & & \\
\hline noreindex & $0.087 * * *$ & $0.122 * * *$ & $0.530 * * *$ & $0.931 * * *$ & $0.721 * * *$ & & & & & & \\
\hline norcindex & $0.152 * * *$ & $0.272 * * *$ & $-0.626 * * *$ & $-0.326 * * *$ & -0.002 & $0.040 * * *$ & & & & & \\
\hline ni_ta & $0.158 * * *$ & $0.355^{* * * *}$ & $-0.069 * * *$ & -0.003 & -0.001 & $0.039 * *$ & $0.110 * * *$ & & & & \\
\hline lev & $-0.149 * * *$ & $-0.102 * * *$ & $-0.106^{* * *}$ & $0.080 * * *$ & -0.156 & $-0.090 * * *$ & -0.022 & $-0.358 * * *$ & & & \\
\hline cash_ta & $0.174 * * *$ & $-0.202 * * *$ & $0.065^{* * * *}$ & $0.044 * * *$ & $0.120 * * *$ & $0.058 * * *$ & $0.043 * * *$ & $0.149 * * *$ & $-0.217 * * *$ & & \\
\hline capex_ta & $0.063 * * *$ & $0.033^{*}$ & -0.014 & $-0.029 *$ & -0.007 & -0.025 & 0.013 & $0.160 * * *$ & $-0.092 * * *$ & $-0.148 * * *$ & \\
\hline Inasset & $-0.194 * * *$ & $0.476 * * *$ & $-0.143 * * *$ & $0.054 * * *$ & $-0.080 * * *$ & $0.114 * * *$ & $0.132 * * *$ & -0.022 & $0.187 * * *$ & $-0.102 * * *$ & 0.025 \\
\hline
\end{tabular}


Table 4(b) Spearman Correlation

\begin{tabular}{|c|c|c|c|c|c|c|c|c|c|c|c|}
\hline & Tobin's Q & $\begin{array}{l}\text { credit } \\
\text { rating }\end{array}$ & norabsdiff & norabsdiff1 & norgindex & noreindex & norcindex & ni_ta & lev & cash_ta & capex_ta \\
\hline $\begin{array}{l}\text { credit } \\
\text { rating }\end{array}$ & $0.324 * * *$ & & & & & & & & & & \\
\hline norabsdiff & $-0.129 * * *$ & $-0.294 * * *$ & & & & & & & & & \\
\hline norabsdiff1 & 0.008 & -0.013 & $0.729 * * *$ & & & & & & & & \\
\hline norgindex & $0.040 * *$ & $-0.125 * * *$ & $0.765 * * *$ & $0.688 * * *$ & & & & & & & \\
\hline noreindex & $0.097 * * *$ & $0.107 * * *$ & $0.550 * * *$ & '0.915*** & $0.725 * * *$ & & & & & & \\
\hline norcindex & $0.235^{*} * *$ & $0.284 * * *$ & $-0.619 * * *$ & $-0.325 * * *$ & -0.033 & 0.014 & & & & & \\
\hline ni_ta & $0.631 * * *$ & $0.354 * * *$ & $-0.115 * * *$ & 0.02 & 0.006 & $0.067 * * *$ & $0.172 * * *$ & & & & \\
\hline lev & $-0.253 * * *$ & $-0.113 * * *$ & 0.001 & $-0.090 * * *$ & $-0.048 * *$ & $-0.105^{* * * *}$ & $-0.064 * * *$ & $-0.358 * * *$ & & & \\
\hline cash_ta & $0.258 * * *$ & $-0.163 * * *$ & 0.028 & $0.067 * * *$ & $0.089 * * *$ & $0.087 * * *$ & $0.045 * *$ & $0.149 * * *$ & $-0.217 * * *$ & & \\
\hline capex_ta & $0.158 * * *$ & $0.153 * * *$ & $-0.049 * *$ & $-0.034 * *$ & $-0.034 *$ & -0.025 & $0.049 * *$ & $0.160 * * *$ & $-0.092 * * *$ & $-0.148 * * *$ & \\
\hline lnasset & $-0.048 * *$ & $0.446 * * *$ & $-0.079 * * *$ & 0.021 & 0.02 & $0.072 * * *$ & $0.122 * * *$ & -0.022 & $0.187 * * *$ & $-0.102 * * *$ & 0.025 \\
\hline
\end{tabular}


Table 5. Fama French 5 factor model with norgindex, norcindex, t-statistics in parentheses

\begin{tabular}{cccc}
\hline & (middle norgindex, middle norcindex) & (high norgindex, low norcindex) & (low norgindex, high norcindex) \\
\hline mktrf & $1.156^{* * *}$ & $1.270^{* * *}$ & $1.157^{* * *}$ \\
& $(29.804)$ & $(28.719)$ & $(33.051)$ \\
smb & $0.435^{* * *}$ & $0.186^{* * *}$ & $0.115^{* * *}$ \\
& $(11.031)$ & $(3.840)$ & $(2.754)$ \\
hml & $0.278^{* * *}$ & $0.363^{* * *}$ & $0.296^{* * *}$ \\
& $(5.223)$ & $(5.500)$ & $(5.015)$ \\
rmw & $0.244^{* * *}$ & -0.037 & $0.335^{* * *}$ \\
& $(4.020)$ & $(-0.533)$ & $(6.178)$ \\
cma & $0.212^{* * *}$ & $0.354^{* * *}$ & $0.321^{* * *}$ \\
& $(3.349)$ & $(4.738)$ & $(4.310)$ \\
cons & -0.162 & $-0.325^{* *}$ & $-0.401^{* * *}$ \\
Sample size & $(-1.444)$ & $(-2.333)$ & $(-2.931)$ \\
\end{tabular}

\begin{tabular}{|c|c|c|c|}
\hline & CG LOW & CG MIDDLE & CG HIGH \\
\hline CSR LOW & $-0.424 * * *$ & $-0.225^{*}$ & $-0.325^{* *}$ \\
\hline CSR MIDDLE & $-0.385^{* * *}$ & -0.162 & -0.155 \\
\hline CSR HIGH & $-0.401 * * *$ & -0.055 & -0.171 \\
\hline
\end{tabular}

\begin{tabular}{|c|c|c|c|c|c|}
\hline & CG lowest quintile & CG 40\% & CG 60\% & CG 80\% & CG highest quintile \\
\hline CSR lowest quintile & $-0.319^{*}$ & -0.132 & 0.219 & $-0.564 *$ & $-0.365^{*}$ \\
\hline CSR 40\% & $-0.425^{*}$ & $-0.689 * * *$ & -0.500 & -0.054 & $-0.405^{*}$ \\
\hline CSR 60\% & $-0.371^{* *}$ & -0.139 & 0.072 & 0.034 & -0.156 \\
\hline CSR 80\% & $-0.649 * * *$ & -0.252 & 0.007 & -0.348 & 0.250 \\
\hline CSR highest quintile & $-0.369^{* *}$ & -0.084 & 0.053 & $-0.580 * *$ & -0.225 \\
\hline
\end{tabular}


Table 6. Fama French 5 factor model with noreindex, norcindex, t-statistics in parentheses

\begin{tabular}{cccc}
\hline & (middle noreindex, middle norcindex) & (high noreindex, low norcindex) & (low noreindex, high norcindex) \\
\hline mktrf & $1.172^{* * *}$ & $1.230^{* * *}$ & $1.112^{* * *}$ \\
& $(33.982)$ & $(25.472)$ & $(27.074)$ \\
smb & $0.515^{* * *}$ & 0.030 & $0.131^{* * *}$ \\
& $(14.311)$ & $(0.538)$ & $(2.695)$ \\
hml & $0.136^{* * *}$ & $0.368^{* * *}$ & $0.315^{* * *}$ \\
& $(2.775)$ & $(4.887)$ & $(4.555)$ \\
rmw & $0.228^{* * *}$ & 0.033 & $0.485^{* * *}$ \\
& $(4.194)$ & $(0.432)$ & $(7.599)$ \\
cma & $0.268^{* * *}$ & $0.407 * * *$ & $0.345^{* * *}$ \\
& $(4.615)$ & $(4.585)$ & $(4.073)$ \\
cons & $-0.173 *$ & $-0.272 *$ & $-0.469 * * *$ \\
Sample size & $(-1.691)$ & $(-1.689)$ & $(-2.889)$ \\
Adjusted R square & 11,225 & 4,193 & 3,563 \\
\hline
\end{tabular}

\begin{tabular}{|c|c|c|c|}
\hline & CG LOW & CG MIDDLE & CG HIGH \\
\hline CSR LOW & $-0.468^{* * *}$ & $-0.301^{* *}$ & $-0.272 *$ \\
\hline CSR MIDDLE & $-0.418^{* * *}$ & $-0.173^{*}$ & -0.290 \\
\hline CSR HIGH & $-0.469 * * *$ & $-0.203^{*}$ & -0.096 \\
\hline
\end{tabular}

\begin{tabular}{|c|c|c|c|c|c|}
\hline & CG lowest quintile & CG 40\% & CG 60\% & CG 80\% & CG highest quintile \\
\hline CSR lowest quintile & -0.665 & -0.031 & -0.135 & $-0.496^{*}$ & $-0.311^{*}$ \\
\hline CSR 40\% & -0.106 & $-0.469^{* * *}$ & $-0.293^{* * *}$ & -0.234 & -0.276 \\
\hline CSR 60\% & 1.392 & 0.965 & 0.636 & -0.331 & -0.822 \\
\hline CSR 80\% & -0.454 & $-0.626^{* * *}$ & -0.189 & $-0.546^{*}$ & -0.122 \\
\hline CSR highest quintile & -0.590 & $-0.528^{* *}$ & -0.190 & -0.263 & -0.092 \\
\hline
\end{tabular}


Table 7. Abnormal return of a portfolio consisting of middle CG and middle CSR VS abnormal return of the other 8 portfolios, t-statistics in parentheses

\begin{tabular}{|c|c|c|c|}
\hline & model1 & & model 2 \\
\hline \multirow[t]{2}{*}{ mktrf } & $1.202 * * *$ & mktrf & $1.215^{* * *} *$ \\
\hline & $(92.882)$ & & $(88.566)$ \\
\hline \multirow[t]{2}{*}{$\mathrm{smb}$} & $0.261 * * *$ & $\mathrm{smb}$ & $0.254 * * *$ \\
\hline & $(17.905)$ & & $(16.392)$ \\
\hline \multirow[t]{2}{*}{$\mathrm{hml}$} & $0.234 * * *$ & $\mathrm{hml}$ & $0.243 * * *$ \\
\hline & (11.661) & & (11.427) \\
\hline \multirow[t]{2}{*}{$\mathrm{rmw}$} & $0.236 * * *$ & rmw & $0.230 * * *$ \\
\hline & (11.620) & & $(10.704)$ \\
\hline \multirow[t]{2}{*}{$\mathrm{cma}$} & $0.293 * * *$ & $\mathrm{cma}$ & $0.302 * * *$ \\
\hline & (12.177) & & $(11.781)$ \\
\hline \multirow[t]{2}{*}{$\operatorname{lnglnc}$} & -0.113 & lnelnc & 0.042 \\
\hline & $(-0.623)$ & & $(0.227)$ \\
\hline \multirow[t]{2}{*}{ lngmnc } & -0.227 & lnemnc & -0.033 \\
\hline & $(-1.294)$ & & $(-0.197)$ \\
\hline \multirow[t]{2}{*}{ lnghnc } & -0.127 & lnehnc & -0.002 \\
\hline & $(-0.739)$ & & $(-0.010)$ \\
\hline \multirow[t]{2}{*}{ mnglnc } & 0.133 & mnelnc & 0.163 \\
\hline & $(0.882)$ & & (1.183) \\
\hline \multirow[t]{2}{*}{ mnghnc } & 0.042 & mnehnc & 0.049 \\
\hline & $(0.274)$ & & $(0.359)$ \\
\hline \multirow[t]{2}{*}{ hnglnc } & -0.142 & hnelnc & 0.052 \\
\hline & $(-0.912)$ & & $(0.295)$ \\
\hline \multirow[t]{2}{*}{ hngmnc } & $-0.272 *$ & hnemnc & -0.212 \\
\hline & $(-1.878)$ & & $(-1.186)$ \\
\hline \multirow[t]{2}{*}{ hnghnc } & -0.224 & hnehnc & -0.116 \\
\hline & $(-1.450)$ & & $(-0.673)$ \\
\hline \multirow[t]{2}{*}{ _cons } & -0.158 & _cons & $-0.271 * * *$ \\
\hline & $(-1.523)$ & & $(-2.875)$ \\
\hline Sample size & 60,533 & Sample size & 54,484 \\
\hline Adjusted R square & 0.147 & $\begin{array}{l}\text { Adjusted R } \\
\text { square }\end{array}$ & 0.147 \\
\hline
\end{tabular}

$\operatorname{lnglnc}=$ binary variable equal to one if a portfolio consists of low CG group and low CSR group based on norgindex and norcindex lngmnc $=$ binary variable equal to one if a portfolio consists of low CG group and middle CSR group based on norgindex and norcindex 
lnghnc $=$ binary variable equal to one if a portfolio consists of low CG group and high CSR group based on norgindex and norcindex mnglnc $=$ binary variable equal to one if a portfolio consists of middle CG group and low CSR group based on norgindex and norcindex

mngmnc $=$ binary variable equal to one if a portfolio consists of middle CG group and middle CSR group based on norgindex and norcindex

mnghnc $=$ binary variable equal to one if a portfolio consists of middle CG group and high CSR group based on norgindex and norcindex

hnglnc $=$ binary variable equal to one if a portfolio consists of high CG group and low CSR group based on norgindex and norcindex

hngmnc $=$ binary variable equal to one if a portfolio consists of high CG group and middle CSR group based on norgindex and norcindex

hnghnc $=$ binary variable equal to one if a portfolio consists of high CG group and high CSR group based on norgindex and norcindex

lnelnc= binary variable equal to one if a portfolio consists of low CG group and low CSR group based on noreindex and norcindex

lnemnc= binary variable equal to one if a portfolio consists of low CG group and middle CSR group based on noreindex and norcindex

lnehnc= binary variable equal to one if a portfolio consists of low CG group and high CSR group based on noreindex and norcindex

mnelnc= binary variable equal to one if a portfolio consists of middle CG group and low CSR group based on noreindex and norcindex

mnemnc $=$ binary variable equal to one if a portfolio consists of middle CG group and middle CSR group based on noreindex and norcindex

mnehnc $=$ binary variable equal to one if a portfolio consists of middle CG group and high CSR group based on noreindex and norcindex

hnelnc $=$ binary variable equal to one if a portfolio consists of high CG group and low CSR group based on noreindex and norcindex

hnemnc= binary variable equal to one if a portfolio consists of high CG group and middle CSR group based on noreindex and norcindex

hnehnc= binary variable equal to one if a portfolio consists of high CG group and high CSR group based on noreindex and norcindex 
Table 8. Tobin's Q of a portfolio consisting of middle CG and middle CSR VS Tobin's Q of the other 8 portfolios, based on norgindex and norcindex or based on noreindex and norcindex, $t$ statistics in parentheses

\begin{tabular}{|c|c|c|c|}
\hline & Tobin's Q & & Tobin's Q \\
\hline \multirow[t]{2}{*}{$\operatorname{lnglnc}$} & -0.239 & lnelnc & $-0.378 * * *$ \\
\hline & $(-1.185)$ & & $(-3.047)$ \\
\hline \multirow[t]{2}{*}{ lngmnc } & $-0.195 *$ & lnemnc & $-0.237 * *$ \\
\hline & $(-1.653)$ & & $(-2.062)$ \\
\hline \multirow[t]{2}{*}{ lnghnc } & 0.464 & lnehnc & 0.137 \\
\hline & (1.318) & & $(0.686)$ \\
\hline \multirow[t]{2}{*}{ mnglnc } & -0.083 & mnelnc & -0.171 \\
\hline & $(-0.672)$ & & $(-1.222)$ \\
\hline \multirow[t]{2}{*}{ mnghnc } & $0.622 * * *$ & mnehnc & $0.588 * *$ \\
\hline & $(3.050)$ & & $(2.112)$ \\
\hline \multirow[t]{2}{*}{ hnglnc } & -0.194 & hnelnc & 0.021 \\
\hline & $(-1.592)$ & & $(0.154)$ \\
\hline \multirow[t]{2}{*}{ hngmnc } & 0.069 & hnemnc & 0.212 \\
\hline & $(0.443)$ & & $(0.809)$ \\
\hline \multirow[t]{2}{*}{ hnghnc } & 0.338 & hnehnc & $0.626 * * *$ \\
\hline & $(1.632)$ & & $(3.313)$ \\
\hline \multirow[t]{2}{*}{ ni_ta } & $3.146 * * *$ & ni_ta & $3.056 * *$ \\
\hline & $(2.957)$ & & $(2.532)$ \\
\hline \multirow[t]{2}{*}{ lev } & $0.951 * *$ & lev & $1.013 * *$ \\
\hline & $(2.414)$ & & $(2.222)$ \\
\hline \multirow[t]{2}{*}{ cash_ta } & $3.334 * * *$ & cash_ta & $3.219 * * *$ \\
\hline & $(4.496)$ & & $(4.337)$ \\
\hline \multirow[t]{2}{*}{ capex_ta } & $7.765 * * *$ & capex_ta & $7.087 * * *$ \\
\hline & $(4.184)$ & & $(3.702)$ \\
\hline \multirow[t]{2}{*}{ lnasset } & $-0.297 * * *$ & lnasset & $-0.358 * * *$ \\
\hline & $(-4.308)$ & & $(-4.455)$ \\
\hline \multirow[t]{2}{*}{ int_cov } & $0.001 * * *$ & int_cov & $0.001 * *$ \\
\hline & $(2.595)$ & & $(2.112)$ \\
\hline \multirow[t]{2}{*}{ cap_inten } & $-1.453 * * *$ & cap_inten & $-1.596 * * *$ \\
\hline & $(-4.931)$ & & $(-4.739)$ \\
\hline \multirow[t]{2}{*}{ subordinate } & $-0.315 * *$ & subordinate & -0.241 \\
\hline & $(-2.065)$ & & $(-1.317)$ \\
\hline \multirow[t]{2}{*}{ _cons } & $4.583 * * *$ & _cons & $5.146 * * *$ \\
\hline & $(5.192)$ & & $(5.066)$ \\
\hline
\end{tabular}




$\begin{array}{lclc}\text { Industry fixed effects } & \text { Yes } & \text { Industry fixed effects } & \text { Yes } \\ \text { Year fixed effects } & \text { Yes } & \text { Year fixed effects } & \text { Yes } \\ \text { Sample size } & 3,430 & \text { Sample size } & 3,048 \\ \text { Adjusted R square } & 0.178 & \text { Adjusted R square } & 0.193\end{array}$

lnglnc= binary variable equal to one if a portfolio consists of low CG group and low CSR group based on norgindex and norcindex

lngmnc $=$ binary variable equal to one if a portfolio consists of low CG group and middle CSR group based on norgindex and norcindex

lnghnc= binary variable equal to one if a portfolio consists of low CG group and high CSR group based on norgindex and norcindex

mnglnc= binary variable equal to one if a portfolio consists of middle CG group and low CSR group based on norgindex and norcindex

mngmnc $=$ binary variable equal to one if a portfolio consists of middle CG group and middle CSR group based on norgindex and norcindex

mnghnc $=$ binary variable equal to one if a portfolio consists of middle CG group and high CSR group based on norgindex and norcindex

hnglnc= binary variable equal to one if a portfolio consists of high CG group and low CSR group based on norgindex and norcindex

hngmnc $=$ binary variable equal to one if a portfolio consists of high CG group and middle CSR group based on norgindex and norcindex

hnghnc= binary variable equal to one if a portfolio consists of high CG group and high CSR group based on norgindex and norcindex

lnelnc= binary variable equal to one if a portfolio consists of low CG group and low CSR group based on noreindex and norcindex

lnemnc= binary variable equal to one if a portfolio consists of low CG group and middle CSR group based on noreindex and norcindex

lnehnc= binary variable equal to one if a portfolio consists of low CG group and high CSR group based on noreindex and norcindex

mnelnc= binary variable equal to one if a portfolio consists of middle CG group and low CSR group based on noreindex and norcindex

mnemnc= binary variable equal to one if a portfolio consists of middle CG group and middle CSR group based on noreindex and norcindex

mnehnc $=$ binary variable equal to one if a portfolio consists of middle CG group and high CSR group based on noreindex and norcindex

hnelnc= binary variable equal to one if a portfolio consists of high CG group and low CSR group based on noreindex and norcindex

hnemnc $=$ binary variable equal to one if a portfolio consists of high CG group and middle CSR group based on noreindex and norcindex

hnehnc= binary variable equal to one if a portfolio consists of high CG group and high CSR group based on noreindex and norcindex 
Table 9. Tobin's Q and nordiff, nordiff1 or norabsdiff1, t-statistics in parentheses

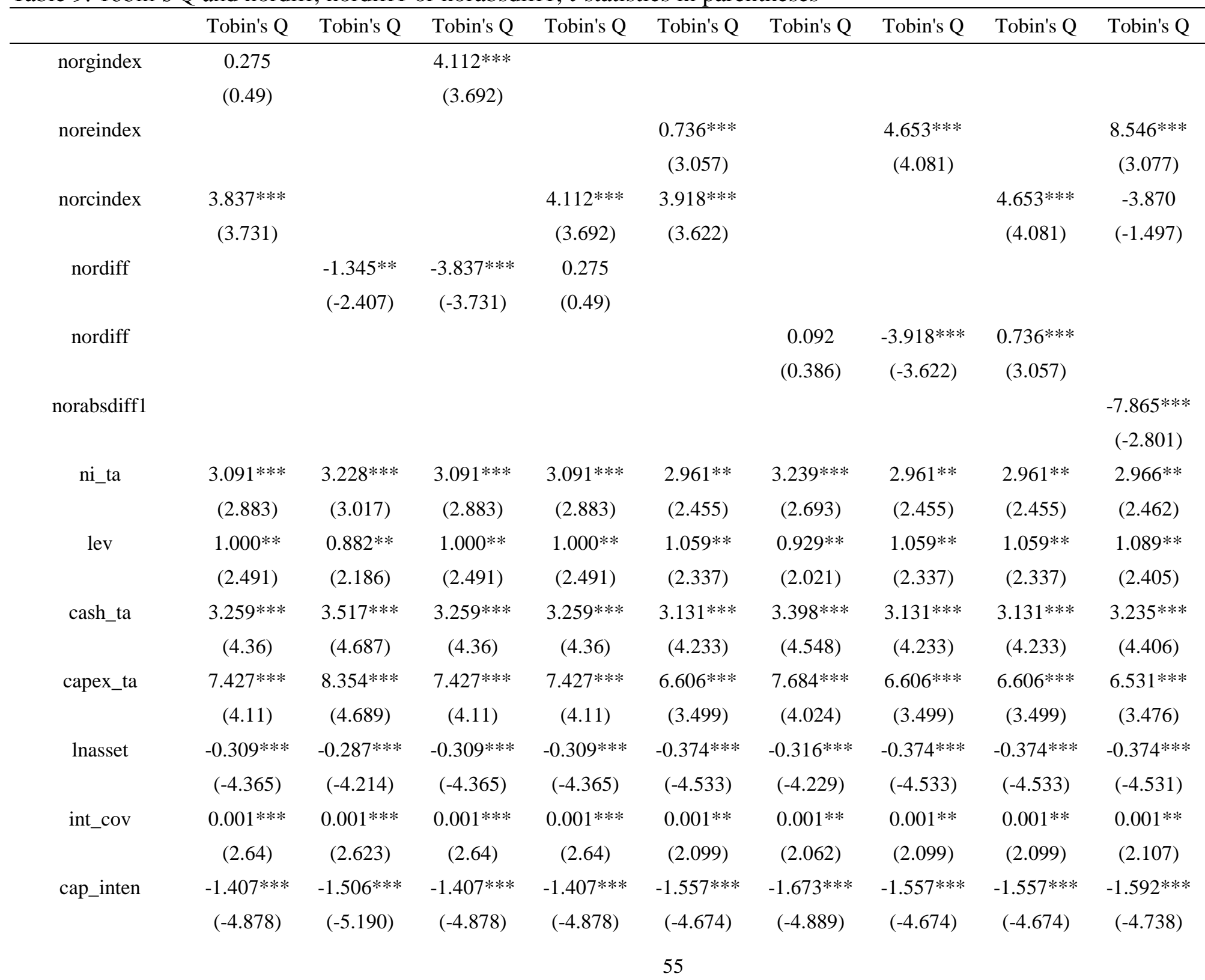




\begin{tabular}{|c|c|c|c|c|c|c|c|c|c|}
\hline subordinate & $\begin{array}{l}-0.299 * \\
(-1.933)\end{array}$ & $\begin{array}{c}-0.328 * * \\
(-2.114)\end{array}$ & $\begin{array}{l}-0.299^{*} \\
(-1.933)\end{array}$ & $\begin{array}{l}-0.299^{*} \\
(-1.933)\end{array}$ & $\begin{array}{c}-0.231 \\
(-1.257)\end{array}$ & $\begin{array}{l}-0.315^{*} \\
(-1.715)\end{array}$ & $\begin{array}{c}-0.231 \\
(-1.257)\end{array}$ & $\begin{array}{c}-0.231 \\
(-1.257)\end{array}$ & $\begin{array}{c}-0.224 \\
(-1.216)\end{array}$ \\
\hline _cons & $\begin{array}{c}4.718^{* * *} \\
(4.373)\end{array}$ & $\begin{array}{c}5.328 * * * \\
(4.841)\end{array}$ & $\begin{array}{c}4.718 * * * \\
(4.373)\end{array}$ & $\begin{array}{c}4.718 * * * \\
(4.373)\end{array}$ & $\begin{array}{c}5.059 * * * \\
(4.42)\end{array}$ & $\begin{array}{c}4.884 * * * \\
(4.955)\end{array}$ & $\begin{array}{c}5.059 * * * \\
(4.42)\end{array}$ & $\begin{array}{c}5.059 * * * \\
(4.42)\end{array}$ & $\begin{array}{c}5.091 * * * \\
(4.441)\end{array}$ \\
\hline $\begin{array}{l}\text { Industry fixed } \\
\text { effects } \\
\text { Year fixed effects }\end{array}$ & & & & & Yes & & & & \\
\hline Sample size & 3,430 & 3,430 & 3,430 & 3,430 & 3,048 & 3,048 & 3,048 & 3,048 & 3,048 \\
\hline Adjusted R square & 0.183 & 0.172 & 0.183 & 0.183 & 0.199 & 0.18 & 0.199 & 0.199 & 0.2 \\
\hline
\end{tabular}


Table 10. credit rating of a portfolio consisting of middle CG and middle CSR VS credit rating of the other 8 portfolios, based on norgindex and norcindex or based on noreindex and norcindex, $\mathrm{t}$-statistics in parentheses

\begin{tabular}{|c|c|c|c|}
\hline & credit rating & & credit rating \\
\hline $\operatorname{lnglnc}$ & $\begin{array}{c}-0.079 \\
(-0.616)\end{array}$ & lnelnc & $\begin{array}{c}-0.184 \\
(-1.325)\end{array}$ \\
\hline $\operatorname{lngmnc}$ & $\begin{array}{c}0.138 \\
(1.223)\end{array}$ & lnemnc & $\begin{array}{c}0.054 \\
(0.484)\end{array}$ \\
\hline lnghnc & $\begin{array}{c}0.169 \\
(1.140)\end{array}$ & lnehnc & $\begin{array}{c}0.197 \\
(1.340)\end{array}$ \\
\hline mnglnc & $\begin{array}{c}-0.207 * * \\
(-2.176)\end{array}$ & mnelnc & $\begin{array}{l}-0.143^{*} \\
(-1.679)\end{array}$ \\
\hline mnghnc & $\begin{array}{c}0.252 * * \\
(2.356)\end{array}$ & mnehnc & $\begin{array}{l}0.189^{*} \\
(1.773)\end{array}$ \\
\hline hnglnc & $\begin{array}{l}-0.212^{*} \\
(-1.742)\end{array}$ & hnelnc & $\begin{array}{c}-0.064 \\
(-0.502)\end{array}$ \\
\hline hngmnc & $\begin{array}{c}-0.183 \\
(-1.570)\end{array}$ & hnemnc & $\begin{array}{l}-0.087 \\
(-0.632)\end{array}$ \\
\hline hnghnc & $\begin{array}{c}-0.082 \\
(-0.546)\end{array}$ & hnehnc & $\begin{array}{c}0.045 \\
(0.274)\end{array}$ \\
\hline ni_ta & $\begin{array}{c}7.008 * * * \\
(12.669)\end{array}$ & ni_ta & $\begin{array}{l}7.213 * * * \\
(12.240)\end{array}$ \\
\hline lev & $\begin{array}{c}-1.893 * * * \\
(-7.387)\end{array}$ & lev & $\begin{array}{c}-1.885^{* * * *} \\
(-6.548)\end{array}$ \\
\hline cash_ta & $\begin{array}{c}-2.575 * * * \\
(-5.169)\end{array}$ & cash_ta & $\begin{array}{c}-2.740 * * * \\
(-4.990)\end{array}$ \\
\hline capex_ta & $\begin{array}{c}-1.563 \\
(-1.355)\end{array}$ & capex_ta & $\begin{array}{c}-1.884 \\
(-1.568)\end{array}$ \\
\hline lnasset & $\begin{array}{c}0.635 * * * \\
(16.454)\end{array}$ & lnasset & $\begin{array}{c}0.685 * * * \\
(15.708)\end{array}$ \\
\hline int_cov & $\begin{array}{c}-0.001 \\
(-1.352)\end{array}$ & int_cov & $\begin{array}{c}-0.001 \\
(-1.333)\end{array}$ \\
\hline cap_inten & $\begin{array}{l}0.366 * * \\
(2.207)\end{array}$ & cap_inten & $\begin{array}{c}0.382^{* *} \\
(2.194)\end{array}$ \\
\hline subordinate & $\begin{array}{c}-0.667 * * * \\
(-7.911)\end{array}$ & subordinate & $\begin{array}{c}-0.636^{* * * *} \\
(-7.070)\end{array}$ \\
\hline Industry fixed effects & Yes & Industry fixed effects & Yes \\
\hline Year fixed effects & Yes & Year fixed effects & Yes \\
\hline
\end{tabular}




\begin{tabular}{cccc} 
Sample size & 2,317 & Sample size & 2,080 \\
Pseudo R sqaure & 0.205 & Pseduo R square & 0.208 \\
\hline
\end{tabular}


Table 11. credit rating and nordiff, nordiff1 or norabsdiff1, $t$-statistics in parentheses

\begin{tabular}{|c|c|c|c|c|c|c|c|c|c|}
\hline & $\begin{array}{l}\text { credit } \\
\text { rating }\end{array}$ & $\begin{array}{l}\text { credit } \\
\text { rating }\end{array}$ & $\begin{array}{l}\text { credit } \\
\text { rating }\end{array}$ & $\begin{array}{l}\text { credit } \\
\text { rating }\end{array}$ & $\begin{array}{l}\text { credit } \\
\text { rating }\end{array}$ & $\begin{array}{l}\text { credit } \\
\text { rating }\end{array}$ & $\begin{array}{l}\text { credit } \\
\text { rating }\end{array}$ & $\begin{array}{l}\text { credit } \\
\text { rating }\end{array}$ & $\begin{array}{l}\text { credit } \\
\text { rating }\end{array}$ \\
\hline norgindex & $\begin{array}{l}-0.862 * * \\
(-2.300)\end{array}$ & & $\begin{array}{c}0.834 \\
(1.491)\end{array}$ & & & & & & \\
\hline noreindex & & & & & $\begin{array}{c}0.006 \\
(0.030)\end{array}$ & & $\begin{array}{c}1.708 * * * \\
(3.707)\end{array}$ & & $\begin{array}{c}2.191 \\
(0.473)\end{array}$ \\
\hline norcindex & $\begin{array}{c}1.695 * * * \\
(4.009)\end{array}$ & & & $\begin{array}{c}0.834 \\
(1.491)\end{array}$ & $\begin{array}{c}1.702 * * * \\
(3.953)\end{array}$ & & & $\begin{array}{c}1.708 * * * \\
(3.707)\end{array}$ & $\begin{array}{c}-0.474 \\
(-0.102)\end{array}$ \\
\hline nordiff & & $\begin{array}{c}-1.224 * * * \\
(-4.345)\end{array}$ & $\begin{array}{c}-1.695 * * * \\
(-4.009)\end{array}$ & $\begin{array}{c}-0.862 * * \\
(-2.300)\end{array}$ & & & & & \\
\hline nordiff1 & & & & & & $\begin{array}{c}-0.270 \\
(-1.551)\end{array}$ & $\begin{array}{c}-1.702 * * * \\
(-3.953)\end{array}$ & $\begin{array}{c}0.006 \\
(0.030)\end{array}$ & \\
\hline norabsdiff1 & & & & & & & & & $\begin{array}{c}-2.197 \\
(-0.474)\end{array}$ \\
\hline ni_ta & $\begin{array}{c}7.050 * * * \\
(12.668)\end{array}$ & $\begin{array}{c}7.103 * * * \\
(12.757)\end{array}$ & $\begin{array}{c}7.050 * * * \\
(12.668)\end{array}$ & $\begin{array}{c}7.050 * * * \\
(12.668)\end{array}$ & $\begin{array}{c}7.146 * * * \\
(12.192)\end{array}$ & $\begin{array}{c}7.333 * * * \\
(12.441)\end{array}$ & $\begin{array}{c}7.146 * * * \\
(12.192)\end{array}$ & $\begin{array}{c}7.146 * * * \\
(12.192)\end{array}$ & $\begin{array}{c}7.142 * * * \\
(12.192)\end{array}$ \\
\hline lev & $\begin{array}{c}-1.878 * * * \\
(-7.273)\end{array}$ & $\begin{array}{c}-1.890 * * * \\
(-7.297)\end{array}$ & $\begin{array}{c}-1.878 * * * \\
(-7.273)\end{array}$ & $\begin{array}{c}-1.878 * * * \\
(-7.273)\end{array}$ & $\begin{array}{c}-1.894 * * * \\
(-6.646)\end{array}$ & $\begin{array}{c}-1.906 * * * \\
(-6.596)\end{array}$ & $\begin{array}{c}-1.894 * * * \\
(-6.646)\end{array}$ & $\begin{array}{c}-1.894 * * * \\
(-6.646)\end{array}$ & $\begin{array}{c}-1.890 * * * \\
(-6.611)\end{array}$ \\
\hline cash_ta & $\begin{array}{c}-2.698 * * * \\
(-5.404)\end{array}$ & $\begin{array}{c}-2.629 * * * \\
(-5.305)\end{array}$ & $\begin{array}{c}-2.698 * * * \\
(-5.404)\end{array}$ & $\begin{array}{c}-2.698 * * * \\
(-5.404)\end{array}$ & $\begin{array}{c}-2.851 * * * \\
(-5.197)\end{array}$ & $\begin{array}{c}-2.686 * * * \\
(-4.991)\end{array}$ & $\begin{array}{c}-2.851 * * * \\
(-5.197)\end{array}$ & $\begin{array}{c}-2.851 * * * \\
(-5.197)\end{array}$ & $\begin{array}{c}-2.838 * * * \\
(-5.184)\end{array}$ \\
\hline capex_ta & $\begin{array}{c}-1.798 \\
(-1.529)\end{array}$ & $\begin{array}{c}-1.559 \\
(-1.311)\end{array}$ & $\begin{array}{c}-1.798 \\
(-1.529)\end{array}$ & $\begin{array}{c}-1.798 \\
(-1.529)\end{array}$ & $\begin{array}{l}-2.234 * \\
(-1.847)\end{array}$ & $\begin{array}{c}-1.701 \\
(-1.391)\end{array}$ & $\begin{array}{l}-2.234 * \\
(-1.847)\end{array}$ & $\begin{array}{l}-2.234 * \\
(-1.847)\end{array}$ & $\begin{array}{l}-2.253 * \\
(-1.860)\end{array}$ \\
\hline lnasset & $\begin{array}{c}0.622 * * * \\
(16.072)\end{array}$ & $\begin{array}{c}0.629 * * * \\
(16.357)\end{array}$ & $\begin{array}{c}0.622 * * * \\
(16.072)\end{array}$ & $\begin{array}{c}0.622 * * * \\
(16.072)\end{array}$ & $\begin{array}{c}0.670 * * * \\
(15.282)\end{array}$ & $\begin{array}{c}0.696 * * * \\
(16.221)\end{array}$ & $\begin{array}{c}0.670 * * * \\
(15.282)\end{array}$ & $\begin{array}{c}0.670 * * * \\
(15.282)\end{array}$ & $\begin{array}{c}0.670 * * * \\
(15.285)\end{array}$ \\
\hline int_cov & $\begin{array}{c}-0.001 \\
(-1.573)\end{array}$ & $\begin{array}{c}-0.001 \\
(-1.535)\end{array}$ & $\begin{array}{c}-0.001 \\
(-1.573)\end{array}$ & $\begin{array}{c}-0.001 \\
(-1.573)\end{array}$ & $\begin{array}{c}-0.001 \\
(-1.618)\end{array}$ & $\begin{array}{c}-0.001 \\
(-1.473)\end{array}$ & $\begin{array}{c}-0.001 \\
(-1.618)\end{array}$ & $\begin{array}{c}-0.001 \\
(-1.618)\end{array}$ & $\begin{array}{c}-0.001 \\
(-1.618)\end{array}$ \\
\hline cap_inten & $\begin{array}{c}0.391 * * \\
(2.345)\end{array}$ & $\begin{array}{c}0.366^{* *} \\
(2.211)\end{array}$ & $\begin{array}{c}0.391 * * \\
(2.345)\end{array}$ & $\begin{array}{c}0.391 * * \\
(2.345)\end{array}$ & $\begin{array}{c}0.412 * * \\
(2.385)\end{array}$ & $\begin{array}{c}0.370 * * \\
(2.143)\end{array}$ & $\begin{array}{c}0.412 * * \\
(2.385)\end{array}$ & $\begin{array}{c}0.412 * * \\
(2.385)\end{array}$ & $\begin{array}{c}0.407 * * \\
(2.345)\end{array}$ \\
\hline subordinate & $\begin{array}{c}-0.660 * * * \\
(-7.742)\end{array}$ & $\begin{array}{c}-0.665 * * * \\
(-7.739)\end{array}$ & $\begin{array}{c}-0.660 * * * \\
(-7.742)\end{array}$ & $\begin{array}{c}-0.660 * * * \\
(-7.742)\end{array}$ & $\begin{array}{c}-0.632 * * * \\
(-6.958)\end{array}$ & $\begin{array}{c}-0.655 * * * \\
(-7.203)\end{array}$ & $\begin{array}{c}-0.632 * * * \\
(-6.958)\end{array}$ & $\begin{array}{c}-0.632 * * * \\
(-6.958)\end{array}$ & $\begin{array}{c}-0.630 * * * \\
(-6.946)\end{array}$ \\
\hline
\end{tabular}




\section{Industry fixed effects}

Year fixed effects

Sample size

2,317

0.205

2,317

0.204

2,317

0.205

2,317

2,080

2,080

2,080

2,080

2,080

Pseudo R square

0.206

0.209

0.209

0.209 
Table 12. Tobin's Q and lagnorabsdiff or lagnorabsdiff1, t-statistics in parentheses

\begin{tabular}{|c|c|c|c|c|c|c|c|c|}
\hline & Tobin's Q & Tobin's Q & Tobin's Q & Tobin's Q & Tobin's Q & Tobin's Q & Tobin's Q & Tobin's Q \\
\hline \multirow[t]{2}{*}{ lagnorgindex } & 0.165 & & $2.962 * * *$ & & & & & \\
\hline & $(0.263)$ & & $(2.710)$ & & & & & \\
\hline \multirow[t]{2}{*}{ lagnoreindex } & & & & & $0.570 * *$ & & $3.237 * * *$ & \\
\hline & & & & & $(2.158)$ & & (3.009) & \\
\hline \multirow[t]{2}{*}{ lagnorcindex } & $2.797 * * *$ & & & $2.962 * * *$ & $2.666^{* * * *}$ & & & $3.237 * * *$ \\
\hline & $(2.727)$ & & & $(2.710)$ & $(2.597)$ & & & (3.009) \\
\hline \multirow[t]{2}{*}{ lagnordiff } & & $-1.033 *$ & $-2.797 * * *$ & 0.165 & & & & \\
\hline & & $(-1.698)$ & $(-2.727)$ & $(0.263)$ & & & & \\
\hline \multirow[t]{2}{*}{ lagnordiff1 } & & & & & & 0.097 & $-2.666^{* * *}$ & $0.570^{* *}$ \\
\hline & & & & & & $(0.368)$ & $(-2.597)$ & $(2.158)$ \\
\hline \multirow[t]{2}{*}{ ni_ta } & $5.475 * * *$ & $5.538 * * *$ & $5.475 * * *$ & $5.475 * * *$ & $5.396 * * *$ & $5.555 * * *$ & $5.396 * * *$ & $5.396 * * *$ \\
\hline & $(4.457)$ & $(4.479)$ & $(4.457)$ & $(4.457)$ & $(3.898)$ & $(3.992)$ & $(3.898)$ & $(3.898)$ \\
\hline \multirow[t]{2}{*}{ lev } & $0.851 * *$ & $0.749 *$ & $0.851 * *$ & $0.851 * *$ & $0.885^{*}$ & 0.791 & $0.885^{*}$ & $0.885^{*}$ \\
\hline & $(1.987)$ & $(1.777)$ & $(1.987)$ & $(1.987)$ & $(1.766)$ & $(1.583)$ & $(1.766)$ & $(1.766)$ \\
\hline \multirow[t]{2}{*}{ cash_ta } & $4.335^{* * *}$ & $4.575^{* * *}$ & $4.335 * * *$ & $4.335^{* * *}$ & $4.155 * * *$ & $4.369 * * *$ & $4.155^{* * *}$ & $4.155^{* * *}$ \\
\hline & $(4.059)$ & $(4.293)$ & $(4.059)$ & $(4.059)$ & $(4.014)$ & $(4.211)$ & $(4.014)$ & $(4.014)$ \\
\hline \multirow[t]{2}{*}{ capex_ta } & $9.475 * * *$ & $10.132 * * *$ & $9.475 * * *$ & $9.475 * * *$ & $9.163 * * *$ & $9.991 * * *$ & $9.163 * * *$ & $9.163 * * *$ \\
\hline & $(3.307)$ & $(3.525)$ & $(3.307)$ & $(3.307)$ & $(3.012)$ & $(3.216)$ & $(3.012)$ & $(3.012)$ \\
\hline \multirow[t]{2}{*}{ lnasset } & $-0.227 * * *$ & $-0.208 * * *$ & $-0.227 * * *$ & $-0.227 * * *$ & $-0.294 * * *$ & $-0.252 * * *$ & $-0.294 * * *$ & $-0.294 * * *$ \\
\hline & $(-2.845)$ & $(-2.698)$ & $(-2.845)$ & $(-2.845)$ & $(-3.063)$ & $(-2.807)$ & $(-3.063)$ & $(-3.063)$ \\
\hline \multirow[t]{2}{*}{ int_cov } & $0.001 * *$ & $0.001 * *$ & $0.001 * *$ & $0.001 * *$ & $0.001 *$ & $0.001^{*}$ & $0.001 *$ & $0.001 *$ \\
\hline & $(2.322)$ & $(2.370)$ & $(2.322)$ & $(2.322)$ & $(1.775)$ & (1.799) & $(1.775)$ & $(1.775)$ \\
\hline \multirow[t]{2}{*}{ cap_inten } & $-1.540 * * *$ & $-1.580 * * *$ & $-1.540^{* * *}$ & $-1.540 * * *$ & $-1.817 * * *$ & $-1.881 * * *$ & $-1.817 * * *$ & $-1.817 * * *$ \\
\hline & $(-4.012)$ & $(-4.105)$ & $(-4.012)$ & $(-4.012)$ & $(-3.810)$ & $(-3.878)$ & $(-3.810)$ & $(-3.810)$ \\
\hline \multirow[t]{2}{*}{ subordinate } & -0.310 & $-0.329 *$ & -0.310 & -0.310 & -0.221 & -0.279 & -0.221 & -0.221 \\
\hline & $(-1.642)$ & $(-1.729)$ & $(-1.642)$ & $(-1.642)$ & $(-1.000)$ & $(-1.253)$ & $(-1.000)$ & $(-1.000)$ \\
\hline
\end{tabular}




\begin{tabular}{ccccccccc} 
_cons & $5.077 * * *$ & $5.310^{* * *}$ & $5.077^{* * *}$ & $5.077^{* * *}$ & $5.711^{* * *}$ & $5.221^{* * *}$ & $5.711^{* * *}$ & $5.711^{* * *}$ \\
& $(4.495)$ & $(4.582)$ & $(4.495)$ & $(4.495)$ & $(5.094)$ & $(5.020)$ & $(5.094)$ & $(5.094)$ \\
Indurty fixed effects & & \multicolumn{7}{c}{ Yes } \\
Year fixed effects & & \multicolumn{7}{c}{0} \\
$\quad$ Sample size & 2,304 & 2,304 & 2,304 & 2,304 & 2,047 & 2,047 & 2,047 & 2,047 \\
Adjusted R square & 0.205 & 0.199 & 0.205 & 0.205 & 0.206 & 0.196 & 0.206 & 0.206 \\
\hline
\end{tabular}


Table 13 Credit rating and lagnorabsdiff or lagnorabsdiff1, t-statistics in parentheses

\begin{tabular}{|c|c|c|c|c|c|c|c|c|}
\hline & $\begin{array}{l}\text { credit } \\
\text { rating }\end{array}$ & $\begin{array}{l}\text { credit } \\
\text { rating }\end{array}$ & $\begin{array}{l}\text { credit } \\
\text { rating }\end{array}$ & $\begin{array}{l}\text { credit } \\
\text { rating }\end{array}$ & $\begin{array}{l}\text { credit } \\
\text { rating }\end{array}$ & $\begin{array}{l}\text { credit } \\
\text { rating }\end{array}$ & $\begin{array}{l}\text { credit } \\
\text { rating }\end{array}$ & $\begin{array}{l}\text { credit } \\
\text { rating }\end{array}$ \\
\hline \multirow[t]{2}{*}{ lagnorgindex } & -0.676 & & 0.908 & & & & & \\
\hline & $(-1.587)$ & & $(1.429)$ & & & & & \\
\hline \multirow[t]{2}{*}{ lagnoreindex } & & & & & 0.012 & & $1.721 * * *$ & \\
\hline & & & & & $(0.055)$ & & $(3.248)$ & \\
\hline \multirow[t]{2}{*}{ lagnorcindex } & $1.584 * * *$ & & & 0.908 & $1.709 * * *$ & & & $1.721 * * *$ \\
\hline & $(3.243)$ & & & $(1.429)$ & $(3.459)$ & & & $(3.248)$ \\
\hline \multirow[t]{2}{*}{ lagnordiff } & & $-1.076 * * *$ & $-1.584 * * *$ & -0.676 & & & & \\
\hline & & $(-3.299)$ & $(-3.243)$ & $(-1.587)$ & & & & \\
\hline \multirow[t]{2}{*}{ lagnordiff1 } & & & & & & -0.277 & $-1.709 * * *$ & 0.012 \\
\hline & & & & & & $(-1.364)$ & $(-3.459)$ & $(0.055)$ \\
\hline \multirow[t]{2}{*}{ ni_ta } & $7.909 * * *$ & $7.936 * * *$ & $7.909 * * *$ & $7.909 * * *$ & $8.456 * * *$ & $8.546 * * *$ & $8.456 * * *$ & $8.456 * * *$ \\
\hline & $(12.467)$ & $(12.425)$ & $(12.467)$ & $(12.467)$ & (13.088) & $(12.931)$ & (13.088) & (13.088) \\
\hline \multirow[t]{2}{*}{ lev } & $-1.984 * * *$ & $-2.001 * * *$ & $-1.984 * * *$ & $-1.984 * * *$ & $-2.046 * * *$ & $-2.050 * * *$ & $-2.046 * * *$ & $-2.046 * * *$ \\
\hline & $(-6.606)$ & $(-6.639)$ & $(-6.606)$ & $(-6.606)$ & $(-6.117)$ & $(-6.052)$ & $(-6.117)$ & $(-6.117)$ \\
\hline \multirow[t]{2}{*}{ cash_ta } & $-3.146^{* * *}$ & $-3.060 * * *$ & $-3.146 * * *$ & $-3.146 * * *$ & $-3.292 * * *$ & $-3.120 * * *$ & $-3.292 * * *$ & $-3.292 * * *$ \\
\hline & $(-5.237)$ & $(-5.126)$ & $(-5.237)$ & $(-5.237)$ & $(-5.011)$ & $(-4.882)$ & $(-5.011)$ & $(-5.011)$ \\
\hline \multirow[t]{2}{*}{ capex_ta } & -2.050 & -1.798 & -2.050 & -2.050 & $-3.064 * *$ & $-2.492 *$ & $-3.064 * *$ & $-3.064 * *$ \\
\hline & $(-1.470)$ & $(-1.293)$ & $(-1.470)$ & $(-1.470)$ & $(-2.104)$ & $(-1.715)$ & $(-2.104)$ & $(-2.104)$ \\
\hline \multirow[t]{2}{*}{ lnasset } & $0.597 * * *$ & $0.606 * * *$ & $0.597 * * *$ & $0.597 * * *$ & $0.646 * * *$ & $0.674 * * *$ & $0.646^{* * *}$ & $0.646 * * *$ \\
\hline & (13.796) & (14.173) & (13.796) & (13.796) & (12.919) & (13.809) & (12.919) & (12.919) \\
\hline \multirow[t]{2}{*}{ int_cov } & $-0.001 * * *$ & $-0.001 * * *$ & $-0.001 * * *$ & $-0.001 * * *$ & $-0.001 * * *$ & $-0.001 * * *$ & $-0.001 * * *$ & $-0.001 * * *$ \\
\hline & $(-3.249)$ & $(-3.042)$ & $(-3.249)$ & $(-3.249)$ & $(-3.966)$ & $(-3.279)$ & $(-3.966)$ & $(-3.966)$ \\
\hline \multirow[t]{2}{*}{ cap_inten } & $0.335^{*}$ & $0.315^{*}$ & $0.335^{*}$ & $0.335^{*}$ & $0.388^{*}$ & $0.355^{*}$ & $0.388^{*}$ & $0.388^{*}$ \\
\hline & $(1.786)$ & $(1.680)$ & $(1.786)$ & (1.786) & (1.954) & $(1.771)$ & (1.954) & (1.954) \\
\hline \multirow[t]{2}{*}{ subordinate } & $-0.770 * * *$ & $-0.775 * * *$ & $-0.770 * * *$ & $-0.770 * * *$ & $-0.711 * * *$ & $-0.734 * * *$ & $-0.711 * * *$ & $-0.711 * * *$ \\
\hline & $(-7.388)$ & $(-7.417)$ & $(-7.388)$ & $(-7.388)$ & $(-6.337)$ & $(-6.673)$ & $(-6.337)$ & $(-6.337)$ \\
\hline Industry fixed effects & & & & & & & & \\
\hline Year fixed effects & & & & & & & & \\
\hline
\end{tabular}




\begin{tabular}{ccccccccc} 
Sample size & 1,680 & 1,680 & 1,680 & 1,680 & 1,513 & 1,513 & 1,513 & 1,513 \\
Pseudo R square & 0.201 & 0.200 & 0.201 & 0.201 & 0.207 & 0.204 & 0.207 & 0.207 \\
\hline
\end{tabular}




\begin{tabular}{|c|c|c|}
\hline Variables & Definition & Source \\
\hline \multicolumn{3}{|c|}{ Dependent variables } \\
\hline Tobin's Q & [book value of assets + (market value of equity - book value of equity)] / book value of assets & Compustat, CRSP \\
\hline \multicolumn{3}{|c|}{$\begin{array}{l}\text { Key independent } \\
\text { variables }\end{array}$} \\
\hline norgindex & normalized value of ([[governance index suggested by Gompers et al. $(2003)] *(-1)+24] / 24)$ & $\begin{array}{c}\text { Andrew Metrick } \\
\text { website }\end{array}$ \\
\hline noreindex & normalized value of $([($ entrenchment index suggested by Bebchuk et al. $(2009)) *(-1)+6] / 6)$ & Bebchuk website \\
\hline norcindex & $\begin{array}{l}\text { normalized value of [(sum of each community strength score }- \text { sum of each community concern score })+ \\
(\text { sum of each environment strength score }- \text { sum of each environment concern score })+ \\
(\text { sum of each diversity strength score }- \text { sum of each diversity concern score })+ \\
(\text { sum of each employee relation strength score }- \text { sum of each employee relation concern score })+ \\
\text { (sum of each product strength score }- \text { sum of each product concern score })]\end{array}$ & KLD \\
\hline nordiff & norgindex - norcindex & \\
\hline nordiff1 & noreindex - norcindex & \\
\hline norabddiff1 & Absolute value of (noreindex-norcindex) & \\
\hline \multicolumn{3}{|c|}{ Control variables } \\
\hline ni_ta & net income scaled by total assets & \\
\hline lev & total debt divided by common/ordinary equity & Compustat \\
\hline cash_ta & cash and cash equivalents scaled by total assets & Compustat \\
\hline capex_ta & total capital expenditures scaled by total assets & Compustat \\
\hline lnasset & nature log of total assets & Compustat \\
\hline int_cov & operating income before depreciation divided by interest and related expense & Compustat \\
\hline cap_inten & gross PPE scaled by total assets & Compustat \\
\hline subordinate & one if the firm has subordinated debt, zero otherwise & Compustat \\
\hline
\end{tabular}




\section{APPENDIX B. EXPANDED LITERATURE REVIEW}

\section{Key prior corporate governance studies}

\section{Corporate Governance and Equity Prices, Gompers, Ishii, and Metrick (2003)}

Gompers et al. (2003) create the governance index, using 22 charter provisions, bylaw provisions, other firm-level rules and coverage under six state takeover laws, leading to 24 unique provisions. Their governance index consists of five groups: 1. tactics for delaying hostile bidders (Delay), 2.voting rights (Voting), 3.director/officer protection (Protection) , 4. other takeover defenses (Other) and 5. state laws (State) ${ }^{13}$.

The governance index measures the level of shareholder rights at about 1500 large US firms during the 1990s. Based on the sample period from 1990 to 1999 , they find that an investment strategy of buying firms in the group with strongest shareholder rights and selling firms in the group with weakest shareholder rights generate abnormal returns of 8.5 percent during their sample period. They also find that firms with weaker shareholder rights have lower firm value, lower profits, lower sales growth, higher capital expenditures, and more corporate acquisitions.

Specifically, they examine the relationship between the governance index and subsequent returns. They find that an investment of $\$ 1$ in the (value-weighted) Dictatorship Portfolio (governance index>=14) on September 1, 1990, when their data begin, became $\$ 3.39$ in December 31, 1999, equivalent to annualized returns of 14 percent. In contrast, a \$1 investment in the Democracy Portfolio (governance index $<=5$ ) became $\$ 7.07$ in December 31, 1999, equivalent to annualized return of 23.3 percent.

They also examine the association of governance index with Tobin's Q from 1990 to

13 More details are shown in the appendix. 
1999 in annual cross-section regressions. They find that their governance index is significantly negatively related to Tobin's Q each year, except for year 1999.

\section{What Matters in Corporate Governance?, Bebchuk, Cohen and Ferrel (2009)}

Based on the Gompers' et al' (2003) governance index, Bebchuk et al. (2009) create the E-index consisting of six provisions: 1. staggered boards, 2. limits to shareholder bylaw amendments, 3. poison pills, 4. golden parachutes, 5. supermajority requirements for mergers, 6. charter amendments. They find that the lower E-index is significantly related to higher Tobin's $\mathrm{Q}$ and higher abnormal returns. They find that the other eighteen provisions in the Gomper et al.'s (2003) governance index is not significantly associated with either Tobin's Q or abnormal returns.

Specifically, they use pooled OLS regressions for the 1992-2002 period to see whether the E-index is related to Tobin's Q. They find that the coefficient on E-index is negative and highly significant with year-fixed effects, or both year-fixed and firm-fixed effects. They also document that the index using other 18 provisions is significantly positively related to Tobin's Q when year-fixed effects are controlled for; however, they report that the coefficient on the index is positive, but not significant, when both year-fixed and firm-fixed effects are controlled for.

They also run annual regressions for the robustness check each year from 1992 to 2002. They report that the coefficient on E-index is negative and significant each year except for the years 1992 and 2001, whereas the coefficients on the index consisting of the other eighteen

provisions do not have statistical significance each year except for 1998 when they find a significantly positive coefficient on the index.

They also examine the relationship between the E index and the abnormal stock returns. They find that firms with a low E index are significantly associated with higher abnormal returns 
both during the 1990-1999 period examined by Gompers, Ishii, and Metrick (2003) and the 1990-2003 period. Furthermore, they find that investment strategies that buy firms in the middle E index group produce positive monthly abnormal returns.

\section{Governance Mechanisms and Equity Prices, Cremers and Nair (2005)}

They explore how the market for corporate control, namely external governance proxied by Gompers et al.'s (2003) G-Score and shareholder activism, namely internal governance proxied by blockholder ownership or public pension fund holdings interact and are related to abnormal returns. They find that an investment strategy of buying firms in the strongest external governance group and selling shorts firms in the weakest external governance group generates an annualized abnormal return of $10 \%$ to $15 \%$ only when pension fund (blockholder) ownership is high.

They also find that an investment strategy of buying firms in the strongest internal governance group and selling short firms in the weakest internal governance group generates the annualized abnormal returns of $8 \%$, only with the presence of high vulnerability to takeovers.

To divide the firms into the strongest external governance group and the weakest one, they do the following:

They simply use a linear transformation of this Gompers et al.'s (2003) G-Score, leading to EXT $=24-G$-Score. As a result, a higher value of EXT means a stronger external governance.

Firms with EXT $\geq 19$ are considered firms in the strongest external governance group and those

with EXT $\leq 10$ are regarded as firms in the weakest external governance group.

Dividing firms into one of four quartiles based on the proxy for internal governance (i.e. percentage of shares held in each firm by the firm's largest institutional blockholder (BLOCK) 
and percentage of shares held by the 18 largest public pension funds (pp), they classify the firms into the strongest internal governance group and the weakest one

\section{Does Weak Governance Cause Weak Stock Returns? An Examination of Firm Operating Performance and Investors' Expectations, Core, Guay and Rusticus (2006)}

They examine whether the findings of Gompers, Ishii, and Metrick's (2003) that firms with weak shareholder rights have significant stock market underperformance. They expect the market to be negatively surprised by the poor operating performance, if the relation between poor governance and poor returns is causal. They report that firms with weak shareholder rights show significant operating underperformance. However, they do not find that this underperformance surprises the market in terms of analysts' forecast errors and earnings announcement returns. Overall, their results indicate that weak governance leads to poor stock returns.

Specifically, they regress future operating performance (measured at time $t$ ) on G_Score and control variables (measured at time $t-1$ ).

Industry-adjusted ROAit $=\alpha+\beta 1 G_{-}$Scorei, $t-1+\beta 2 \log M V E i, t-1+\beta 3 \operatorname{logBMEi,t}-1$.

They interpret a significantly positive or negative estimate of $\beta 1$ as evidence of a relationship between the strength of shareholder rights and operating performance.

Industry-adjusted ROAit $=\alpha+\beta 1$ Dicti, $t-1+\beta 2 \log M V E i, t-1+\beta 3 \log B M E i, t-1$,

where Dict is a binary variable that takes the value of 1 if the firm is in the weakest corporate governance group, and 0 if the firm is in the strongest corporate governance group. If the coefficient $\beta 1$ on Dict is significantly negative (positive), this is regarded as evidence that weaker corporate governance is associated with lower (higher) operating performance.

When the dependent variable is a firm's operating income after depreciation in the 1991- 
99 period, they find that the coefficient on G-index is negative and highly significant in the years 1993, 94 and 95. In other years, the coefficients are negative, but not significant. When the dependent variable is a firm's operating income before depreciation, the coefficient on G_Score is negative and significant at the 5\% level in the years 1993 and 94 . In other years, the coefficients are negative, but not significant.

They restrict the sample to the weakest corporate governance and strongest governance groups. When the dependent variable is a firm's operating income after depreciation, Dict has the negative and significant coefficient only when the year is 1994 . When they regress operating income before depreciation on Dict, they do not find the significant coefficient every year.

Analysts' forecast errorit $=\alpha+\beta 1 G$-indexi, $t-1+\beta 2 \log M V E i, t-1+\beta 3 \log B M E i, t-1$. Analysts' forecast errorit $=\alpha+\beta 1$ Dicti,t $-1+\beta 2 \log M V E i, t-1+\beta 3 \log B M E i, t-1$.

If analysts are surprised by the differential operating performance of weak and strong governance firms, they expect to find negative coefficients on G_Score and Dict in regressions, respectively.

When the dependent variable is the analysts' forecast error, they find no significant coefficient on G_Score except for the year 1996 when the coefficient on G-index is positive and highly significant. As far as Dict is concerned, they find no significant coefficient every year.

\section{A Reexamination of Corporate Governance and Equity Prices, Johnson, Moorman and Sorescu (2009)}

They reexamine long-term abnormal returns for portfolios sorted on governance characteristics based on Gompers et al.'s (2003) G_Score. They find that firms in the strong corporate governance group and firms in the weak corporate governance group are distributed 
differently across industries. Based on industry clustering tests, they find statistically zero long-term abnormal returns for portfolios sorted on G_Score.

\section{Corporate governance and firm valuation, Brown and Caylor (2006)}

They create Gov-Score, a summary governance measure based on 51 firm-specific provisions representing both internal and external governance. They create Gov-Score, for 1868 firms as of February 1, 2003, since it precedes the effective dates of both the relevant provisions of the Sarbanes-Oxley Act and those enacted by major US stock exchanges.

They regress Tobin's Q on Gov_Score and controls. The coefficient on Gov_Score is positive and highly significant. They also regresses Tobin's Q on all 51 provisions underlying Gov_Score and controls. They find that the coefficients on the following six governance factors are positive and significant: (1) board members are elected annually (no staggered board); (2) company either has no poison pill or a pill that was shareholder approved; (3) option repricing did not occur within the last three years; (4) directors are subject to stock ownership guidelines; (5) all directors attended at least $75 \%$ of board meetings or had a valid excuse for non-attendance; and (6) average options granted in the past three years as a percent of basic shares outstanding did not exceed 3\% (i.e., option burn rate is not excessive).

\section{Effect of Corporate Governance on Bond Ratings and Yields: The Role of Institutional Investors and Outside Directors, Bhojraj and Sengupta (2003)}

Using the sample period 1991-1996, they find that bond ratings (yields) on new debt issues are positively (negatively) associated with the percentage of shares held by the institutions and the fraction of the board made up of outside directors

In order to examine possible effects of concentrated ownership, they use two variables in some regressions: 
1. percentage of company's common stock held by the five largest institutional owners of the firm.

2. percentage of company's stock held by institutions owning 5\% or more of the company's stock Specifically, they find that the percentage of shares held by the institutions and the fraction of outside directors are positively associated with credit ratings at the $1 \%$ significance level when either of the two concentrated ownership variables is not controlled for. When the percentage of company's common stock held by the five largest institutional owners of the firm is controlled for, the significance of the coefficient on the percentage of the company's common stock held by institutions decreases from $1 \%$ to $5 \%$, while the coefficient on the concentrated ownership variable is negative and highly significant. When the percentage of company's stock held by institutions owning 5\% or more of the company's stock is controlled for, its coefficient is negative and highly significant, while the coefficients on the two governance variables are negative and highly significant.

They also document that the percentage of shares held by the institutions and the fraction of outside directors are significantly negatively related to bond yields. However, when credit ratings are controlled for, the coefficients on the two governance variables are negative, but not significant. Without credit ratings controlled for, but with either of the two concentration ownership variables controlled for, the coefficients on the two governance variables are negative and significant and the coefficients on the concentration ownership variables are positive and significant.

In order to see whether governance variables have greater rating improving effects or greater yield lowering effects for poorly rated debt than high-quality debt, they interact the two governance variables with a dummy variable equal to one if the bond has Moody's rating of A or 
higher and zero, otherwise. They find that the coefficients on the interaction of the percentage of shares held by the institution and the dummy variable and the interaction of the fraction of outside directors and the dummy variable are negative and highly significant, documenting that governance variables have greater rating improving effects for poorly rated debt. As far as the bond yield is concerned, they report that the coefficient on the interaction of the fraction of outside directors and the dummy variable is positive and highly significant, whereas the coefficient on the interaction of the percentage of shares held by the institution and the dummy variable is negative, but not significant, partially documenting that governance has a greater yield lowering effect for poorly rated debt than high-quality debt.

\section{The effects of corporate governance on firms'credit ratings, Ashbaugh-Skaife, Collins and}

\section{LaFond (2006)}

Ashbaugh-Skaife et al. (2006) find that takeover defenses, board independence, board stock ownership and board expertise are positively related to credit ratings, while the number of blockholders and CEO power are negatively associated with credit ratings. They also document that CEOs of firms with speculative-grade credit ratings are overcompensated to a greater degree than CEOs of firms with investment-grade ratings.

In this dissertation, the key governance variables are as follows:

BLOCK: number of block holders, where block is defined at the 5\% ownership level \%INST: \% of shares held by institutional investors

\%INSIDE: \% of shares held by insiders (officers and directors)

G_SCORE: governance score from Gompers et al., 2003

\%BRD_IND: \% of independent directors on the board

CEOPOWER: Composite score representing the power of the CEO where a firm receives one 
point if the CEO is the chairman of the board, and one point for each committee (compensation, nominating, audit) that the CEO sits on \%BRD_EXPERT: \% of independent directors that hold seats on other firms' boards \%BRD_STOCK: \% of directors that own stock in the firm GOVERNANCE_POLICY: one if the firm has a formal governance policy, zero otherwise \%FINCOM_INSIDE: \% of insiders on the finance committee \%NOM_IND: \% of independent directors on the nominating committee \%COMP_IND: \% of independent directors on the compensation committee Specifically, they find that BLOCK is negatively related to credit ratings at the $1 \%$ significance level. The coefficient on G_Score is positive, but marginally significant. The coefficient on \%BRD_IND is positive and marginally significant. The coefficient on CEOPOWER is negative and marginally significant. They also find that \%BRD_EXPERT and \%BRD_STOCK are significantly positively related to credit ratings at the $1 \%$ significance level.

They also divide credit ratings into investment grade and speculative grade. They create a dummy variable equal to one if a firm's credit rating is investment grade and zero otherwise. They regress the dummy variable on governance variables and control variables in logistic regressions. They report that BLOCK has a negative coefficient at the $1 \%$ significance level. The coefficient on G_SCORE is positive at the $10 \%$ significance level. \%BRD_STOCK has a positive coefficient at the $1 \%$ significance level. Other governance variables are not significant.

They try to shed light on why firms have weaker governance, paying higher costs of debt. 
They find that when the dependent variable is the CEO's salary, \%COMP_CEOAPP ${ }^{14}$, CEOPOWER and BRDSIZE ${ }^{15}$ are positively related to the CEO's salary at the $1 \%$ significance level. When the dependent variable is compensation consisting of salary and bonus, the significance of CEOPOWER disappears; \%COMP_CEOAPP and BRDSIZE are still positively associated with the compensation at the $1 \%$ significance level. When the dependent variable is total compensation consisting of salary, bonus, other annual pay, total value of restricted stock granted, total value of stock options granted, long-term incentive payouts, and all other total pay, CEOPOWER has a positive coefficient at the $10 \%$ significance level; the coefficients on \%COMP_CEOAPP and BRDSIZE are positive and significant at the 5\% level. With these results, they conclude that some firms operate in weak governance to allow CEOs more compensation.

\section{Earnings management and corporate governance: the role of the board and the audit} committee, Xie, Davidson III, and DaDalt (2003)

They examine whether stronger corporate governance deters earnings management. They find that firms with board and audit committee members who have corporate or financial backgrounds engage less in earnings management. They also find that higher board and audit committee meeting frequency is associated with lower discretionary accruals.

They regress discretionary accruals on one governance variable such as CEO duality, number of board meetings and percentage of outside directors without control variables. They find that the coefficients on number of board meeting and percentage of outside directors are negative and marginally significant. They also find that the percentage of corporate outsider

14 percentage of outside independent directors on the compensation committee appointed by the CEO

15 number of directors on the board 
directors and board size are negatively associated with discretionary accruals at the 5\% significance level.

They also regress discretionary accruals on percentages of outside directors, corporate directors, blockholder directors, board size, percent of blockholder vote, average outside director tenure, and number of board meetings. They find that board size is negatively associated with discretionary accruals at the $5 \%$ significance level and average outside director tenure is positively related to discretionary accruals at the $5 \%$ significance level.

In addition, they regress discretionary accruals on number of audit committee meetings, proportions of outside corporate members and outside investment banking members, and audit committee size. They find that number of audit committee meetings, proportion of outside corporate members and proportion of outside investment banking members are significantly negatively linked to discretionary accruals.

\section{Accounting conservatism and corporate governance, Lara, Osma and Penalva (2009)}

They find that strong governance firms have significantly higher levels of conditional accounting conservatism. They provide evidence that strong governance leads to a higher level of accounting conservatism and not vice versa.

They measure total governance (Totgov), combining the following proxies:

1. External governance: Entrenchment index of Cremers and Nair (2005)

2. CEO involvement: indicator variable equal to one if the CEO is also the chairman of the board and zero otherwise

3. Board composition: proportion of top executives who serve on the board.

4. Board effectiveness: inverse of number of board meetings

$\mathrm{Xt}=\mathrm{b} 0+\mathrm{b} 1 \mathrm{Dt}+\mathrm{b} 2$ Totgovt $+\mathrm{b} 3 \mathrm{Rt}+\mathrm{b} 4 \mathrm{DtTotgovt}+\mathrm{b} 5 \mathrm{R}$ Totgovt $+\mathrm{b} 6 \mathrm{DtR} t+\mathrm{b}$ DtRtTotgovt 
+error

With the equation above, they explore whether firms with stronger governance have significantly higher levels of conditional accounting conservatism. They find that b7 has the negative and significant coefficient, which means the firms with stronger governance exhibit higher levels of accounting conservatism.

\section{Key prior CSR studies}

\section{Stakeholder welfare and firm value, Jiao (2010)}

Using data from KLD, Jiao (2010) shows that the CSR score consisting of employees, diversity, customers, communities, and environment is positively related to Tobin's Q. She finds that the positive impacts are driven by employees and environment, suggesting that good employee relations and environmental performance serve as reputation which will be beneficial for shareholder value maximization.

In this dissertation, the CSR score is measured as follows:

CSR score $=$ firm's total stakeholder strength score minus its total stakeholder weakness score. The total stakeholder strength score is computed by adding the points a firm receives for community, diversity, environment, employee, and product strengths; the total stakeholder weakness score is computed by adding the points the firm receives for community, diversity, environment, employee, product weaknesses, in the KLD database.

Community: firm's total community strength score minus its total community weakness score. The total community strength score is calculated by adding the points a firm receives for community strength; the total community weakness score is calculated by adding the points the firm receives for community weakness.

Diversity: firm's total diversity strength score minus its total diversity weakness score. The 
total diversity strength score is calculated by adding the points a firm receives for diversity strength; the total diversity weakness score is calculated by adding the points the firm receives for diversity weakness.

Environment: firm's total environmental strength score minus its total environmental weakness score. The total environmental strength score is calculated by adding the points a firm receives for environmental strength; the total environmental weakness score is calculated by adding the points the firm receives for environmental weakness.

Employee: firm's total employee strength score minus its total employee weakness score. The total employee strength score is calculated by adding the points a firm receives for employee strength; the total employee weakness score is calculated by adding the points the firm receives for employee weakness.

Product: firm's total product strength score minus its total product weakness score. The total product strength score is calculated by adding the points a firm receives for product strength; the total product weakness score is calculated by adding the points the firm receives for product weakness.

To see whether there is a difference between Tobin's Q of firms with high CSR scores and that of firms with low CSR scores, she first examines the mean difference between them, based on the 1992-2003 period and finds that the mean Tobin's Q of firms within the high CSR score group is 2.40 and that of firms within the low CSR score group is 2.02, whose difference is statistically significant. In the OLS regressions, she finds that a CSR score is positively related to Tobin's $Q$ at the 5\% significance level. To mitigate endogeniety, she runs 2SLS with an instrument variable, an indicator of positive earnings in the previous year and find that a CSR score is positively associated with Tobin's Q at the 5\% significance level. 
She further divides the CSR score into five component scores: community, diversity, environment, employee and product scores. In OLS regressions, she finds that only the diversity score is positively associated with Tobin's $\mathrm{Q}$ at the $1 \%$ significance level, whereas the coefficients on the other four component scores are not significant. In 2SLS regressions, she finds that the environment score has a positive coefficient at the $10 \%$ significance level and the coefficient on the employee score is positive and significant at the 5\% level.

\section{Corporate Social Responsibility and Credit Ratings, Attig, Ghoul, Guedhami, and Suh} (2013)

Attig et al. (2013) find that higher CSR is associated with higher credit ratings and that the individual components of CSR, namely, community relations, diversity, employee relations, environmental performance, and product characteristics influence firms' credit ratings. They suggest that CSR conveys non-financial information that rating agencies rely on to evaluate firms' credit ratings, and credit agencies consider better CSR firms more creditworthy, which, in turn, lowers financing costs resulting from debt issuance.

Based on 11,662 US firm-year observations over the 1991-2010 period, they report that investment in CSR is associated with higher credit ratings. Their CSR score ${ }^{16}$ calculation is the same as Jiao (2010), except that Attig et al. (2013) include human rights. When they regress credit ratings on the CSR score, they find that the coefficient on the CSR score is positive and highly significant. They also regress credit ratings on the CSR strength score which equals the number of strengths in the community, diversity, employee, environment, human rights and product and find that the CSR strength score is positively associated with credit ratings at the $1 \%$ significance level. Regressing credit ratings on the CSR concern score which equals the

${ }^{16}$ firm's total stakeholder strength score minus its total stakeholder weakness score 
numbers of concerns in the community, diversity, employee, environment, human rights and product, they document that the CSR concern score has a negative coefficient at the $1 \%$ significance level. Finally, they regress credit ratings on the CSR strength score and CSR concern score and report that the coefficients on the CSR strength score and the CSR concern score are positive and negative, respectively and highly significant.

They also regress credit ratings on each of the following:

CSR_COM_S: The community score equals the number of strengths minus the number of concerns in the community qualitative issue area

CSR_DIV_S: The diversity score equals the number of strengths minus the number of concerns in the diversity qualitative issue area

CSR_EMP_S: The employee relations score equals the number of strengths minus the number of concerns in the employee relations qualitative issue area

CSR_ENV_S: The environment score equals the number of strengths minus the number of concerns in the environment qualitative issue area

CSR_HUM_S: The human rights score equals the number of strengths minus the number of concerns in the human rights qualitative issue area

CSR_PRO_S: The product score equals the number of strengths minus the number of concerns in the product qualitative issue area

They find that the coefficients on all of these are positive and highly significant, except that CSR_HUM_S is negative and not significant.

They also check the robustness of their results across different sample periods. The CSR score is positively associated with credit ratings at the $1 \%$ significance level, when the sample period is from 1991 to 2000 . The CSR also has a positive coefficient at the $1 \%$ 
significance level when the sample period is from 2001 to 2010.

3. The impact of corporate social responsibility on the cost of bank loans, Goss and Roberts (2011)

They explore the association between corporate social responsibility (CSR) and bank debt. Using a sample of 3996 loans to US firms, they find that firms with social responsibility concerns pay higher cost of bank debt than firms with good social performance. However, they do not find that CSR strength is related to cost of bank loan.

They measure the cost of bank loans as the spread which is the amount the borrower pays in basis points over LIBOR for each loan dollar drawn down.

When they regress spread on CSR strength and concern and controls, they find that the coefficient on CSR strength is negative, but not significant, whereas the coefficient on CSR concern is positive and highly significant. They also regress spread on CSR strength, concern and the interaction of strength and concern. They find that CSR concern has a positive coefficient at the $1 \%$ significance level, while the coefficient on CSR strength is negative, but not significant. The interaction of strength and concern has the negative coefficient at the 5\% significance level, though the coefficient magnitude is small.

4. Does corporate social responsibility affect the cost of capital?, Ghoul, Guedhami, Kwok, and Mishra (2011)

They link corporate social responsibility (CSR) to the cost of equity capital for a large sample of US firms. They document that higher CSR score is related to lower cost of equity. They further find that the association is driven mainly by employee relations, environmental policies, and product strategies. They also show that firms in two "sin" industries, namely, tobacco and nuclear power, have higher firms' cost of equity. 
With the 1992-2007 period, they find that CSR score is negatively related to cost of equity at the $1 \%$ significance level. However, when they restrict the sample period to the 1990 s, they do not find the significance of the coefficient on CSR score. When they restrict the sample period to the 2000s, they find that CSR score is significantly negatively associated with cost of equity. They also regress cost of equity on each dimension underlying CSR score. They find that higher employee dimension score, higher environment dimension score, and higher product dimension score are significantly negatively related to cost of equity.

\section{Voluntary Nonfinancial Disclosure and the Cost of Equity Capital: The Initiation of} Corporate Social Responsibility Reporting, Dhaliwal, Li, Tsang, and Yang (2011)

They document that a high cost of equity capital in the previous year is related to initiation of disclosure of CSR activities in the current year and that initiating firms with superior social responsibility performance have a subsequent decrease in the cost of equity capital. Further, dedicated institutional investors and analyst coverage increase for initiating firms with strong CSR. Moreover, the analysts' forecast errors and dispersion decrease for firms with strong CSR.

To test whether a high cost of equity in the previous year leads to CSR disclosure in the current year, they employ the following the logistic model.

$\log ($ probDISCI i,t $/(1-$ probDISCli,t $)=0+1 \mathrm{COC} i, t-1+$ control variables where DISCli,t is a dummy variable equal to 1 if firm i discloses a standalone CSR report for the first time in year t (initiating firm-years or initiators), and 0 (non-initiating firm-years or noninitiators), otherwise. COC is the ex ante cost of equity capital in the year prior to first-time CSR disclosure. 
When they regress the dummy variable, DISCI on COC, they find that the coefficient on COC is positive and highly significant.

To examine whether CSR disclosure attracts institutional investors, they employ the following regression:

$\Delta \mathrm{INSTi}, \mathrm{t}+1=0+1 \mathrm{DISCIi}, \mathrm{t}+$ Controls

INST represents stock ownership by institutional investors.

Though the coefficient on DISCI is positive, it is not significant. However, when they restrict the sample to firms with top $50 \%$ social performance measured as KLD data, they find that DISCI has the positive coefficient at the $1 \%$ significance level.

They also investigate whether financial analysts are more willing to cover firms after they initiate CSR disclosure, whether the level of forecast accuracy increases and whether forecast dispersion decreases when CSR reports are available. When they regress analyst followings on DISCI, they do not find significance on DISCI. However, when they restrict the sample to firms grouped in the top $50 \%$ corporate social performance, they find that DISCI is positively related to analyst followings at the 5\% significance level. However, they do not find significance of DISCI when the sample is restricted to firms grouped in the bottom $50 \%$ corporate social performance. Regressing analysts' forecast errors on DISCI, they find that DISCI is negatively associated with analysts' forecast errors at the 5\% significance level. When the sample is restricted to the top $50 \%$ social performance firms, the coefficient on DISCI is negative and marginally significant. They do not find significance of DISCI with the sample restricted to the bottom 50\% social performance firms. As far as analysts' forecast dispersion is 
concerned, they find that DISCI is negatively linked to analysts' forecast dispersion at the $1 \%$ significance level, when the sample is restricted to the top 50\% social performance firms. However, they do not find significance of DISCI with the full sample or the sample restricted to the bottom $50 \%$ social performance.

\section{Nonfinancial Disclosure and Analyst Forecast Accuracy: International Evidence on} Corporate Social Responsibility Disclosure, Dhaliwal, Radhakrishnan, Yong and Yang (2012)

They examine whether disclosure of nonfinancial information is related to analyst forecast accuracy, using firm-level data from 31 countries. They use the issuance of standalone corporate social responsibility (CSR) reports to proxy for disclosure of nonfinancial information. They find that the issuance of stand-alone CSR reports is linked to lower analyst forecast error. This association is stronger in more stakeholder-oriented countries where CSR performance is more likely to affect firm financial performance. This association is also stronger for firms and countries that do not have transparent financial disclosure.

The key independent variable is NONFIN, an indicator variable that equals 1 if the concerned firm issues stand-alone CSR reports during the year, and 0 otherwise. When regressing analysts' forecast error on NONFIN, they find that the coefficient on NONFIN is negative and highly significant.

To examine whether the association between CSR disclosure and analysts' forecast accuracy is stronger among countries with a higher level of stakeholder orientation, they measure STAKE which is principal factor of STAKELAW, CSRLAW, PUBAWARE, and PUBAWARE1

STAKELAW: measure primarily assessing the legal environment of a country in protecting labor rights

CSRLAW: indicator variable equal to one if the concerned country has mandatory disclosure 
requirements on CSR issues only for industrial companies or only for pension funds; 2 if the country has mandatory disclosure requirements for both industrial companies and pension funds, and 0 otherwise

PUBAWARE: measure of public awareness of CSR issues at the country level PUBAWARE1: alternative measure of public awareness of CSR issues at the country level primarily based on opinion surveys among global corporate executives STAKE: principal factor of STAKELAW, CSRLAW, PUBAWARE, and PUBAWARE1 Regressing analysts' forecast error on the interaction of NONFIN and STAKE, they find that the interaction term is negative and highly significant, which means that the relationship between CSR disclosure and analysts' forecast accuracy is stronger among countries with a higher level of stakeholder orientation.

To examine whether CSR disclosure plays a complementary role in financial transparency, they measure financial opaqueness at the country level, CFIN which is countrylevel financial opaqueness or the mean rank score of a country's average CIFAR ratings in three years (1991, 1993, and 1995), multiplied by (1). Regression analysts' forecast error on the interaction of NONFIN and CFIN, they find the coefficient on the interaction term negative, which means that the positive association between CSR disclosure and analyst forecast accuracy is stronger among firms with a higher level of financial opacity.

7. Is Earnings Quality Associated with Corporate Social Responsibility?, Kim, Park, and Wier (2012)

They explore whether socially responsible firms behave more ethically in terms of their financial reporting, particularly earnings management. They find that socially responsible firms are less likely to engage in both accruals earnings management and real earnings management. 
They also find that firms with good social performance are less likely to be the subject of SEC investigations.

When they regress the absolute discretionary accruals on CSR Score, they find that higher CSR score is linked to the lower absolute discretionary accruals at the $1 \%$ significance level. When they restrict the sample to firms with positive discretionary accruals, they find that the coefficient on CSR Score is negative and highly significant. When restricting the sample to firms with negative discretionary accruals, they find that the coefficient on CSR Score is positive and highly significant, which means that firms with higher CSR score engage less in incomedecreasing earnings management. They also regress three proxies of real earnings management on CSR Score and find that firms with greater social performance engage less in real earnings management.

Further, they use logistic regression to see whether firms with the higher CSR score are less likely to be subject of SEC investigations. They find that a higher CSR score is negatively associated with SEC investigations at the 5\% significance level, when the dependent variable is a binary variable equal to one if a firm has AAER against its CEO or CFO and zero, otherwise.

\section{Is Doing Good for You?, How Corporate Charitable Contributions Enhance Revenue} Growth, Lev, Petrovits and Sureshradhakrishnan (2010)

They examine the association between corporate philanthropy growth and sales growth using a charitable contributions made by U.S. public companies in the period 1989-2000. With Granger causality tests, they find that charitable contributions are significantly associated with future revenue, whereas revenue is marginally related to contributions. The results are stronger for firms highly sensitive to consumer perception. They also report a positive association between contributions and customer satisfaction. 
$\log (\operatorname{SALEit} / \operatorname{SALEi}(\mathrm{t}-1))=\mathrm{a} 0+\mathrm{a} 1 \log (\operatorname{GIFTi}(\mathrm{t}-1) / \operatorname{GIFTi}(\mathrm{t}-2))+\mathrm{a} 2 \log (\operatorname{GIFTi}(\mathrm{t}-2) / \operatorname{GIFTi}(\mathrm{t}-3))$

+ control variables + error $-(1)$

As far as the empirical results are concerned in equation (1), al is positive and significant at the $5 \%$ level, while a 2 is positive and marginally significant.

$\log (\operatorname{GIFTit} / \operatorname{GIFTi}(\mathrm{t}-1)) \quad=\quad \mathrm{a} 0 \quad+\quad \mathrm{b} 1 \log (\operatorname{SALEi}(\mathrm{t}-1) / \operatorname{SALEi}(\mathrm{t}-2)) \quad+\quad \mathrm{b} 2$ $\log (\operatorname{SALEi}(\mathrm{t}-2) /$ SALEi $(\mathrm{t}-3))+$ control variables + error

In empirical results concerned in equation (2), b1 is positive and marginally significant, whereas b2 is positive, but not significant.

They divide the firms into firms with high customer sensitivity and those with low customer sensitivity. When the sample is restricted to firms with high customer sensitivity, they find that a1 and a 2 have positive coefficients at the 5\% significance level. However, when the sample is restricted to firms with low customer sensitivity, they do not find significance of a1 and a2. When the sample is restricted to either firms with high customer sensitivity or those with low customer sensitivity, they do not find significance of b1 and b2.

They further regress customer satisfaction on corporate giving. They find that corporate giving is positively associated with customer satisfaction at the $5 \%$ significance level. When the sample is restricted to firms with high customer sensitivity, they find that corporate giving is positively linked to customer satisfaction at the $1 \%$ significance level. However, the coefficient on corporate giving is positive, but marginally significant when the sample is restricted to firms with low customer sensitivity. 


\section{The Corporate Social Performance Financial Performance Link, Waddock and Graves}

(1997)

They report the results of the empirical linkages between corporate social performance and financial performance. They find that corporate social performance (CSP) is positively associated with prior financial performance, supporting the notion that slack resource availability and CSP are positively correlated. They also find that CSP is positively related to future financial performance, supporting the idea that good management and CSP are positively correlated.

When they regress corporate social performance on one-year lagged ROA, they find that one-year lagged ROA is positively linked to corporate social performance at the $1 \%$ significance level. However, regressing corporate social performance on one-year lagged ROE, they find the positive coefficient on one-year lagged ROA at the $10 \%$ significance level. When the key independent variable is one-year lagged return on sales (ROS), the coefficient on one-year lagged ROS is positive at the $5 \%$ significance level.

They also regress ROA, ROE and ROS on one-year lagged corporate social performance. They find the positive coefficients on one-year lagged corporate social performance when the dependent variable is ROA or ROS. However, when the dependent variable is ROE, they do not find significance of one-year lagged corporate social performance.

\section{Corporate Social Responsibility and Financial Performance: Correlation or}

\section{Misspecification?, McWilliams and Siegel (2000)}

They note that the CSR literature reports a positive, negative, and neutral impact of corporate social responsibility (CSR) on financial performance. They suggest that this inconsistency is due to incorrect empirical analysis. To have better econometric analysis, they 
estimate the effect of CSR by regressing firm performance on corporate social performance, and several control variables. They find that the model is misspecified when it does not control for investment in R\&D. Due to this misspecification, upwardly biased estimates of CSR occur. When the model is properly specified, they find that CSR has a neutral effect on financial performance.

When they regress accounting profits on corporate social performance and controls, they find that corporate social performance is positively associated with accounting profits at the $1 \%$ significance level. However, when they regress accounting profits on corporate social performance, $\mathrm{R} \& \mathrm{D}$ expenditures and the same controls, they do not find significance of the coefficient on corporate social performance. 


\section{REFERENCES}

Albert, M. 1993. Capitalism Vs. Capitalism. Basic Books.

Ashbaugh-Skaifea H., Collins D.W. and LaFond R. 2006. The effects of corporate governance on firms' credit ratings. Journal of Accounting and Economics 42, 203-243.

Ashforth, B., Harrison, S. and Corley, K. 2008. Identification in Organizations: An Examination of Four Fundamental Questions. Journal of Management 34(3), 325-374.

Atkas, N., Bodt, E. and Cousin, J. 2011. Do financial markets care about SRI? Evidence from mergers and acquisitions. Journal of Banking and Finance 35(7), 1753-1761.

Attig, N., Ghoul, E. S., Guedhami, O., and Suh, J. 2013. Corporate Social Responsibility and Credit Ratings. Journal of Business Ethics, 117, 679-694

Baker, H. K. and Powell, G. E. 2005. Understanding Financial Management: A Practical Guide. Malden, MA: Blackwell Publishing.

Barnea, A. and Rubin, A. 2010. Corporate Social Responsibility as a Conflict Between Shareholders. Journal of Business Ethics, 97, 71-86.

Barton, D. 2011. Capitalism for the Long Term. Harvard Business Review, 89(3): 84-91.

Barton, D and Wiseman, M. 2014. Focusing Capital on the Long Term. Harvard Business Review, 44-51.

Bebchuk, L. A., Cohen, A., and Ferrell, A. 2009. What matters in corporate governance? Review of Financial Studies 22(2), 783-827.

Bhojraj, S. and Sengupta, P. 2003. Effects of corporate governance on bond ratings and yields: The role of institutional investors and outside directors. Journal of Business, 76, 455-475

Blume, M. E., Lim, F., and Mackinlay, A. C. 1998. The declining credit quality of U.S. corporate debt: Myth or reality. Journal of Finance, 53, 1389-1413. 
Brown, L. D., and Caylor, M. L. 2006. Corporate governance and firm valuation. Journal of Accounting and Public Policy 25, 409-434

Carhart, Mark M., 1997, On persistence in mutual fund performance, Journal of Finance, 52: 5782.

Claessens, S., Djankov, S., Fan, J.and Lang, L. 2002. Disentangling the Incentive and Entrenchment Effects of Large Shareholders. Journal of Finance 57, 2741-71.

Clark, G., Feiner, A. and Viehs, M. 2015. From the Stockholder to the Stakeholder: How Sustainability Can Drive Financial Outperfomance. Working paper.

Coombes, P., \& Watson, M. 2000. Three surveys on corporate governance. McKinsey Quarterly, 4: 74-77.

Cremers, K. J. Martijn, and Vinay B. Nair. 2005. Governance Mechanisms and Equity Prices. Journal of Finance, 60(6): 2859-2894.

Sun, W., and Cui, K. 2013. Linking corporate social responsibility to firm default risk, European Management Journal, 32(2), 275- 287.

Deng, X., Kang, J-K and Low, B. S. 2013. Corporate social responsibility and stakeholder value maximization: Evidence from mergers. Journal of Financial Economics 110, 87-109.

Dervin, B. 1983. An overview of sense-making research: Concepts, methods and results. Paper presented at the annual meeting of the International Communication Association. Dallas, TX.

Dervin, B. 1992. From the mind's eye of the user: The sense-making qualitative-quantitative methodology. In Glazier, J. and Powell, R. R. Qualitative research in information management (p. 61-84). Englewood, CA: Libraries Unlimited.

Dervin, B. 1996. Given a context by any other name: Methodological tools for taming the unruly beast. Keynote paper, ISIC 96: Information Seeking in Context. 1-23. 
Dhaliwal, D., S. Eheitzman, and O.Z. Li, 2009. Taxes, Leverage, and the Cost of Equity Capital. Journal of Accounting Research 44, 691-723.

Dhaliwal, D.S., Li, O. Z., Tsang, A. and Yang, Y. G. 2011. Voluntary Nonfinancial Disclosure and the Cost of Equity Capital: The Initiation of Corporate Social Responsibility Reporting. The Accounting Review 86(1), 59-100.

Donaldson, T. and Preston, Lee E. 1995. The Stakeholder Theory of the Corporation: Concepts, Evidence, and Implications. Academy of Management Review 20 (1): 65-91.

Eccles, R., Serafeim, G and Krzus, M. P. 2011. Market interest in nonfinancial information. Journal of Applied Corporate Finance 23(4), 113-127.

Edmans, A. 2011. Does the Stock Market Fully Value Intangibles? Employee Satisfaction and Equity Prices. Journal of Financial Economics 101(3), 621-640.

Corporate Governance in the European Union: A Plan to Move Forward, May 21, 2003.

Fama, E., French, K.,1993. Common risk factors in the returns on stocks and bonds. Journal of Financial Economics 33, 3-56.

Fama, E., French, K. 2015. A Five-Factor Asset Pricing Model. Journal of Financial Economics 116(1), 1-22.

Ferrell, A., H. Liang, and L. Renneboog. 2016. Socially Responsible Firms. Journal of Financial Economics, forthcoming.

FitchRatings, 2004. Credit policy special report, evaluating corporate governance: the bondholders' perspective, New York.

Friedman, M., 1970. The social responsibility of business is to increase its profits. New York Times Magazi ne, September 13, 1970. 
Galema, R., Plantinga, A. and Scholtens, B. 2008. The Stocks at Stake: Return and Risk in Socially Responsible Investment. Journal of Banking and Finance 32(12), 2646-2654.

Gardberg, N.A. and C. Fombrun, 2006, “Corporate Citizenship: Creating Intangible Assets Across Institutional Environment,” Academy of Management Review 31, 329-346.

Ghoul, E. S., Guedhami, O., Kwok, C. C. Y. and Mishra D. R. 2011. Does Corporate Social Responsibility Affect the Cost of Capital? Journal of Banking and Finance 35(9), 2388-2406.

Godfrey, P.C., 2005. The Relationship Between Corporate Philanthropy and Shareholder Wealth: A Risk Management Perspective. Academy of Management Review 30, 777-798.

Godfrey, P.C., C.B. Merrill, and J.M. Hansen, 2009. The Relationship Between Corporate Social Responsibility and Shareholder Value: An Empirical Test of the Risk Management Hypothesis. Strategic Management Journal 30, 425-445.

Gompers, P., Ishii, J. and Metrick, A., 2003. Corporate governance and equity prices. Quarterly Journal of Economics 118, 107-155.

Goss, A. and Roberts G. S. 2011. The Impact of Corporate Social Responsibility on the Cost of Bank Loans. Journal of Banking and Finance 35(7), 1794-1810.

Hambrick DC,Werder A and Zajac EJ. 2008. New directionsin corporate governance research. Organization Science 19: 381-385.

Harvey C.R., Lins, K.V. and Roper, A.H. 2004. The effect of capital structure when expected agency costs are extreme. Journal of Financial Economics 74(1), 3-30.

Hillman, AJ, and GD Keim, 2001, Shareholder value, stakeholder management, and social issues: What's the bottom line?, Strategic Management Journal, 125-139.

Hilscher, J. and Wilson, M. i. 2013. Credit ratings and credit risk: is one measure enough? Meetings Paper, AFA 2013 San Diego. 
Huang, X. and Watson, L. 2015. Corporate Social Responsibility Research in Accounting. Journal of Accounting Literature 34, 1-16.

Jensen, M. C. and Meckling, W. H. 1976. Theory of the Firm: Managerial Behavior, Agency Costs and Ownership Structure. Journal of Financial Economics, 3(4), 305-360.

Jensen, M. 2010. Value Maximization, Stakeholder Theory, and the Corporate Objective Function. Journal of Applied Corporate Finance 22(1), 32-42.

Jia, J., Luce, M. F., and Fischer, G. W. 2004. Consumer preference uncertainty: Measures of attribute conflict and extremity. Project paper: Wharton-SMU Research Center, 1-42.

Jiao, Y. 2010. Stakeholder Welfare and Firm Value. Journal of Banking and Finance 34(10), 2549-2561.

Jiraporn, P., Jiraporn, N., Boeprasert, A., and Chang, K. (2014). Does corporate social responsibility improve credit ratings? Evidence from geographic identification, Financial Management, 43(3), 505-531.

Jo, H. and Harjoto, M.A. 2011. Corporate Governance and Firm Value: The Impact of Corporate Social Responsibility Journal of Business Ethics 103(3), 351-383.

Kalcheva, I., Lins, K. 2007. International Evidence on Cash Holdings and Expected Managerial Agency Problems. Review of Financial Studies.

Klein, G., Moon, B. and Hoffman, R.F., 2006. Making sense of sensemaking I: alternative perspectives. IEEE Intelligent Systems 21 (4), 70-73.

Koonce, L., and M. Mercer. 2005. Using Psychology Theories in Archival FinancialAccounting Research. Journal of Accounting Literature 24:175-214.

Lang, M., V. L. Karl, and M. Mark. 2012. Transparency, liquidity, and valuation: international evidence on when transparency matters most. Journal of Accounting Research 50(3): 729-774. 
Lins, K. 2003. Equity Ownership and Firm Value in Emerging Markets. Journal of Financial and Quantitative Analysis 38, 159-84.

Liu, Y. and Jiraporn,P. 2010, The Effect of CEO Power on Bond Ratings and Yields. Journal of Empirical Finance 17, 744-762.

Louis, M. R. 1980. Surprise and sensemaking: What newcomers experience in entering unfamiliar organizational settings. Administrative Science Quarterly, 25: 226-251.

McConnell, J. J., and H. Servaes. 1990. Additional Evidence on Equity Ownership and Corporate Value. Journal of Financial Economics 27, 595-612.

McGuire, J., A. Sundgren, and T. Schneeweis. 1988. Corporate Social Responsibility and Firm Financial Performance,” Academy of Management Journal 31, 854-872.

Mills, J. H. 2003. Making Sense of Organizational Change. Routledge, London, UK.

Oikonomou, I., Brooks, C., and Pavelin, S. 2012. The impact of corporate social performance on financial risk and utility: A longitudinal analysis. Financial Management, 41, 483-515.

Park, J. S. and Rhee, M. 2013. Reputation Incongruence and the Preference of Stakeholder: In the Context of MBA Ranking, Article in Academy of Management Annual Meeting Proceedings

Patriotta, G. 2003. Sensemaking on the shop floor: Narratives of knowledge in organizations. Journal of Management Studies 40(2), 349-376.

Pastor, L. and Stambaugh, R.F. 2003. Liquidity risk and expected stock returns, Journal of Political Economy 111, 642--685.

Peloza, J. 2006. Using Corporate Social Responsibility as Insurance for Financial Performance: A Meta-Analysis. Organizational Science 24, 403-441. 
Petersen, M.A. 2009. Estimating standard errors in finance panel data sets: Comparing approaches. Review of Financial Studies 22, 435-480.

Pratt, M. G. 2000. The good, the bad, and the ambivalent: Managing identification among Amway distributors. Administrative Science Quarterly 45, 456-493.

Reinhardt, F., Stavins, R., and Vietor, R. 2008. Corporate Social Responsibility Through an Economic Lens. Review of Environmental Economics and Policy 2(2), 219-239.

Russell, D. M., Stefik, M. J., Pirolli, P. and Card, S. K. 1993. The cost structure of sensemaking. Paper presented at the INTERCHI '93 Conference on Human Factors in Computing Systems, Amsterdam.

Sharfman, M.P. and Fernando, C.S. 2008. Environmental Risk Management and the Cost of Capital. Strategic Management Journal 29, 569-592.

Sharma, N. 2006. Sensemaking: Bringing theories and tools together. Proceedings of the American Society for Information Science and Technology, 43(1), 1-8.

Starks, L. T. 2009. Corporate governance and corporate social responsibility: What do investors care about? What should investors care about? EFA keynote speech. The Financial Review, 44(4), 461-468.

Starbuck, W. H., and F. J. Milliken. 1988. Executives' perceptual filters: What they notice and how they make sense. In D. C. Hambrick (ed.), The Executive Effect: Concepts and Methods for Studying Top Managers: 35-65. Greenwich, CT: JAI Press.

Sun, W. and Cui, K. 2013. Linking corporate social responsibility to firm default risk. European Management Journal 32(2), 275-287.

Surroca and Tribo 2008. Managerial Entrenchment and Corporate Social Performance. Journal of Business Finance and Accounting, 35(5-6). 748-760. 
The New York Times, 2016. Climate Risks Present Stock Pitfalls.

The New York Times, 2016. Some Heresy on Wall Street: Look Past the Quarter.

Walls, J. L., Berrone, P. and Phan P. H. 2012. Corporate Governance and Environmental Performance: Is There Really a Link? Strategic Management Journal 33: 885-913.

Weick, K. 1988. Enacted sensemaking in crisis situations. Journal of Management Studies, 25, $305-317$.

Weick, K. E. 1995. Sensemaking in organizations Newbury Park, CA: Sage.

Weick, K. E. and Sutcliffe, K. M. 2001. Managing the Unexpected. Jossey-Bass, San Francisco, CA.

Weick, K. E., Sutcliffe, K. M. and Obstfeld, D. 2005. Organizing and the process of sensemaking. Organization Science, 16(4), 409-421.

Witt, M. A. and Redding, G. 2012. The spirits of Corporate Social Responsibility: senior executive perceptions of the role of the firm in society in Germany, Hong Kong, Japan, South Korea and the USA. Socio-Economic Review 10, 109-134.

Zingales, L. 2000. In Search of New Foundations. Journal of Finance 55(4), 1621-1653. 